\title{
Un baño privado en el arrabal occidental de Madinat Qurtuba
}

\author{
A private bath in the western suburbs of Madinat Qurtuba \\ Rafael Clapés Salmoral *
}

\begin{abstract}
RESUMEN
La presencia de baños de carácter privado en viviendas de arrabal es un hecho poco frecuente, como demuestran las publicaciones existentes al respecto y los resultados de las excavaciones realizadas hasta el momento en el parcelario andalusí. A continuación analizaremos un valioso ejemplo documentado en el arrabal occidental de Qurtuba, que ha permitido ampliar el conocimiento de estas instalaciones islámicas y entender cómo se adaptan los modelos de baños públicos al ámbito doméstico.
\end{abstract}

Palabras clave: Baño privado, Qurtuba, califal, arrabal.

\section{INTRODUCCIÓN}

Las intervenciones arqueológicas llevadas a cabo en el sector occidental de la ciudad de Córdoba durante los últimos años ha propiciado la exhumación de grandes superficies de arrabal islámico, permitiendo de esta forma iniciar un exhaustivo estudio tanto de la articulación general como de la evolución del urbanismo andalusí en toda esta área suburbana. La ejecución de los planes parciales, contemplados en el Plan General de Ordenación Urbana de Córdoba (P.G.O.U. 200I) para la zona oeste de la ciudad, ha afectado a terrenos que han tenido

\begin{abstract}
The presence of private baths in suburb houses is not a frequent fact, as it is demonstrated by the related existing publications and the results of excavations done up to now in the Andalusi hamlet. We will analyze a valuable example documented in the occidental suburbs of Qurtuba, which has allowed spreading the knowledge of these islamic spa facilities and understand how the models of public baths are adapted to the domestic field.
\end{abstract}

Key words: Private bath, Qurtuba, caliphate, suburb.

una actividad fundamentalmente agrícola desde el abandono de las viviendas islámicas, hacía la mitad del s.XI, lo que ha posibilitado que la trama de arrabales se hallara prácticamente intacta. Los datos obtenidos de estas excavaciones permiten comprobar y completar la información aportada por las fuentes literarias árabes ', y esclarecer de algún modo todo el proceso urbanizador que en el s.X tiene lugar en el vasto terreno ubicado entre el lienzo occidental de la muralla de Madinat Qurtuba y la ciudad palatina de Madinat al-Zahra' (ACIÉN; VALLEJO, 1998; CASTRO, 2005; DORTEZ, 20 I 0; MURILLO et alii, 1999; 20I0; RUIZ et alii, 2010).

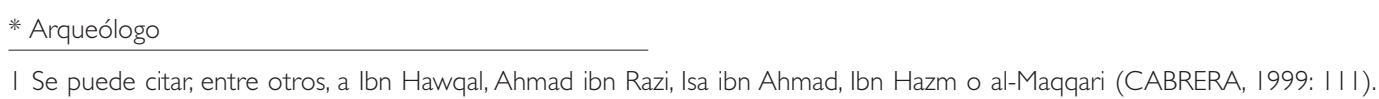


En nuestro caso (Lam. I), intervenimos en un solar ${ }^{2}$ que contenía una superficie de arrabal excavado de aproximadamente 5800 $\mathrm{m}^{2} 3$. Los resultados son muy interesantes, $y$ aluden a una intensa actividad edilicia en este sector occidental (al-Yanib al-Garbi) de Madinat Qurtuba. La parcela se encuentra embutida en un área de arrabal definida, al norte, por una de las principales vías de comunicación en uso desde época romana, como es el Camino viejo de Almodóvar, que vendría a coincidir con la vía que conectaba las ciudades de Qurtuba e Isbiliya por la margen norte del Río Guadalquivir ${ }^{4}$. Al sur, a pocos metros, se extiende una amplia zona de cementerio islámico, documentado en los solares situados en el sector meridional del Plan Parcial (LEÓN; CASAL, 20 l0: 665) ${ }^{5}$.

La secuencia de ocupación de la parcela se inicia con unos estratos de deposición, cuya cronología no avanzaba más allá del s.ll d.C., pero la actividad constructiva no comienza hasta la tardoantigüedad, con una finalidad funeraria ${ }^{6}$, como se comprobó parcialmente durante los trabajos de excavación de un vertedero islámico que afectaba a estos niveles de enterramiento. El siguiente momento edilicio hay que encuadrarlo en época emiral, relacionado con una serie de estructuras en el área suroriental del solar ${ }^{7}$ que fueron amortizadas en la mitad del s. X por la construcción del arrabal califal ${ }^{8}$. Éste no pervive más allá de los primeros años del s.XI, a consecuencia de la fitna. A partir de este momento, no se vuelve a construir en el terreno de esta parcela, que se destinará al cultivo hasta la actualidad?

El entramado urbanístico de época califal (Fig. I ), que se encuentra aún en fase de estudio, se organiza en torno a tres calles principales, que definen tres manzanas de casas ${ }^{10}$, dispuestas de forma ortogonal y orientadas noroeste-

2 El solar en cuestión es la Manzana 14 del Plan Parcial O-7, actualmente situado entre la C/ Escritor Conde de Zamora, la C/ Escritora Emilia Pardo Bazán, la C/ Escritora María Teresa de León y el Camino Viejo de Almodóvar. En el proceso de excavación y documentación de los vestigios hallados en este emplazamiento intervinieron como técnicos arqueólogos D. Manuel Cobo Aguilera y Dña. Ester Martínez Jurado.

3 La intervención no agotó la secuencia estratigráfica del terreno, por lo que no fue posible completar la evolución general del arrabal ni de las viviendas en particular. Esta información estaba prevista que se obtuviera en el posterior Seguimiento Arqueológico, prescrito por la Delegación Provincial de Cultura de Córdoba. La actual crisis financiera, que ha afectado en gran medida al sector de la construcción, ha propiciado que el terreno haya cambiado de propietario, por lo que los trabajos de seguimiento de la nueva edificación se están realizando por otro equipo de arqueólogos, sin que actualmente haya concluido.

4 Esta vía parte desde la Bab 'amir al-Qurasí, actual Puerta de Gallegos, ubicada en el lateral occidental de la muralla de la ciudad. Se la ha identificado con la calzada romana Corduba-Hispalis (MELCHOR, 1995). En origen se trataba de una vía secundaria, permaneciendo así hasta los inicios del Califato, cuando adquiere mayor importancia por la expansión urbanística del área occidental (BERMúDEZ, 1993: 274).

5 Cuando se realizaron estas intervenciones, pudimos comprobar, in situ, como una calle que documentamos en el ángulo sureste de nuestro solar, se prolongaba hacía el sur, delimitando el espacio habitacional del espacio funerario.

6 Se documentó un posible recinto funerario, del que se excavó el muro oriental de cierre. Al oeste de este muro, que presentaba una fábrica de opus africanum, se exhumaron dos sepulturas. Los enterramientos estaban realizados en una fosa simple en el terreno, con cubierta de tégulas. Los individuos estaban dispuestos en posición decúbito supino, con las manos cruzadas sobre las caderas y la cabeza orientada hacia el oeste. Este recinto podría vincularse con las pequeñas áreas cementeriales que surgen a partir del s.VI en el suburbium occidental de Corduba, tras la desaparición o abandono de las necrópolis paganas altoimperiales. Se trata de espacios funerarios asociados a centros de especial significación religiosa, por lo general basílicas martiriales, distribuidas extramuros de la ciudad (MURILLO et alii, 2010: 5I5-5I8).

7 Las estructuras se encuentran a nivel de cimentación y muy fragmentadas, con una disposición ortogonal, si bien algunos de los muros varían ligeramente su orientación, dando lugar a espacios trapezoidales. Estas edificaciones emirales a extramuros de la medina surgen a partir del s.IX, aglutinados en torno a un foco de atracción previo, como grandes propiedades (munyat o balat), un centro de culto cristiano o un antiguo vicus (MURILLO et alii, 2004; 20 I0a: 535-540).

8 La detección de las estructuras emirales fue posible en gran medida a la presencia de un gran patio-jardín de época califal, que permitió el rebaje de su superficie. Este patio contaba con una estructura hidráulica (posiblemente una fuente) y un pozo de noria, unidos por canalizaciones cerámicas. Se pudo constatar como los muros se encontraban arrasados por las zanjas de cimentación de las canalizaciones y en altura estaban desmochados a la cota del nivel de suelo del patio. La técnica empleada es similar a la documentada en las excavaciones del arrabal de Saqunda (CASAL, 2008), es decir, muros formados por cantos rodados dispuestos en espiga (en este caso se usa también calizas), con un refuerzo en alguno de los ángulos con sillares de calcarenita. Los pavimentos estaban realizados con gravas y fragmentos cerámicos, y en los niveles de abandono se hallaron tégulas de pequeño formato y moldura con poco resalte, documentados en contextos emirales también en otras ciudades, como Mérida (MATEOS, ALBA, 200 I). Varias estructuras del arrabal califal aprovechan los muros de esta fase previa como primera hilada de cimentación.

9 Los niveles de colmatación y abandono del arrabal se encontraban cubiertos por el manto vegetal, a escasos $50 \mathrm{~cm}$ de la superficie.

I0 La zona central de la parcela, que no se excavó al no tener afección en la nueva edificación, podría contener otra manzana, aunque no se ha podido confirmar arqueológicamente. 
sureste. Se han identificado, al menos, cuarenta viviendas, un probable zoco y un área con un amplio jardín, cuya futura interpretación ayudará a entender la evolución de toda la zona. Las casas cuentan con una planta compleja, resultado de las diversas reformas sufridas "I, y en la mayoría de ellas no se ha podido excavar toda su extensión, debido a que su superficie excedía los límites de la intervención. Las características de las viviendas no difieren de las documentadas en todo este sector de la ciudad (CASTRO, 2005; DORTEZ, 20 I0; MURILLO et alii, 1999), organizadas en torno al patio 12 donde se encuentra el pozo de agua para su abastecimiento, favorecido en este caso porque el nivel freático se encuentra superficial, entre los siete y ocho metros de profundidad con respecto a la cota del suelo ${ }^{13}$. Como norma general, cada casa contaba con un patio, sin embargo, en dos viviendas se detectó un doble patio. Tanto el agua sobrante de los pozos, como la recogida de la lluvia, se eliminaban a través de canalizaciones que partían desde el patio hasta verter en las atarjeas de las calles, que discurrían bajo el zaguán de la residencia. Los pozos negros, ubicados en las calles, recibían las aguas fecales desde las letrinas de las casas, aunque, en algunos casos, se encontraban en el interior de las viviendas en pequeñas estan- cias $^{14}$. El resto de las habitaciones del ámbito doméstico (salón, alcoba, zaguán, letrina, etc.) se disponen en torno al patio, y su número varía de una casa a otra, dependiendo de sus dimensiones. En altura, las viviendas dispondrían de una sola planta, ya que no se hallaron restos de escaleras hacia un segundo nivel ${ }^{15}$. El arrabal muestra varios puntos de interés, pero nos detendremos en una casa que cuenta con un elemento que la distingue de las demás: un baño privado.

\section{EL BAÑo DENTRO DEL ÁMBITO PRIVADO. EVOLUCIÓN DESDE EL PERIODO ROMANO HASTA ÉPOCA ANDALUSí}

\section{I La etapa clásica y tardoantigua}

Los espacios destinados al baño dentro de viviendas particulares están presentes ya en época romana (GARCIA-ENTERO, 2006). En el mundo clásico se les identifica como balnea, y presentan unas dimensiones menores que las termas, ya que éstas cuentan con una funcionalidad pública y por lo tanto sus dependencias debían ser de mayor envergadura. Los balnea se encuentran dentro del entorno doméstico,

I | Generalmente se trata de subdivisiones de espacios. En algunas viviendas se han documentado hasta cuatro fases constructivas.

12 La tipología es variada, ya que depende de la presencia de andén, de pozo, de la fábrica del pavimento y de otros elementos más escasos, como albercas o arriates.

13 En algunas de las casas que no tenían los pozos colmatados de tierra, era posible comprobar cómo todavía circulaba agua en el fondo del encañado. La superficialidad del nivel freático es común en este sector occidental de la ciudad (VÁZQUEZ, 20 I0: 649-650).

14 La presencia de pozos negros al interior de la vivienda fue documentada en tres casas, además de en el baño privado. Esta ubicación está asociada a reformas en las viviendas y modificación del parcelario. Esto propicia que, en algunos casos, la distancia desde la letrina hasta la calle fuera insalvable a través de un canal, que podría obstruirse. Por tanto, se construye el pozo negro en una estancia interior, cerca de la letrina. La ubicación de pozos negros en espacios internos de la vivienda está bien documentada. Se puede encontrar en una habitación aislada, con acceso desde un callejón (REKLAITYTE, 2006: 23I), en establos (CAMACHO et alii, 2004: 217), ya que así se alejan los malos olores y se aprovecha la materia fecal como abono de los campos (REKLAITYTE, 2006: 23I) También en el patio de la casa, aunque es poco común (REKLAITYTE, 2005: 218) y como caso excepcional, en el salón, a consecuencia de la alteración de la planimetría inicial, ya que posiblemente, originalmente, se encontrara al aire libre (NAVARRO; JIMÉNEZ, 1996: 554; 2010: 222).

15 En el patio de una de las viviendas, se documentó el derrumbe de su muro meridional, que tenía fábrica tapial y se encontraba enlucido con mortero de cal por sus dos caras. El paramento arrojaba una altura de aproximadamente cinco metros, lo que podría estar indicando la existencia de una segunda planta. Es interesante el hecho de que el revestimiento aparece corrido en toda su longitud, sin marcas de mechinales que indicaran un posible forjado de segunda planta. El zócalo del muro, que se conserva in situ, no contaba con una gran anchura, por lo que hay que mantener ciertas precauciones con respecto a este planteamiento. En otras ciudades de al-Andalus se han hallado huellas de planta alta, como el despoblado de Siyasa (NAVARRO; JIMENEZ, I 996; 20 I I: I I 2I I3) o la casa de Ya'far en Madinat al-Zahra (VALLEJO, 1990; 20 I 0;VALLEJO et alii, 2004). En Córdoba, algunos de los muros documentados en las excavaciones realizadas en la ciudad tienen cierta envergadura para pensar en la presencia de una segunda planta para algunos casos, aunque no se habían podido confirmar arqueológicamente (MURILLO, FUERTES, LUNA, I999). Esta afirmación se está revisando, y contamos con algunos ejemplos, como el barrio almohade documentado en los jardines del Palacio de Orive (RUIZ et alii, 2003), donde se hallaron adobes en los rellenos interiores de algunas habitaciones, que podrían estar relacionados con azoteas o algorfas (LEÓN; BLANCO, 20I0: 7I4). 
haciendo su aparición en la Península Ibérica en las décadas finales del s.ll a.C. Este fenómeno se generaliza en el alto imperio, a lo largo del s.l d.C., adquiriendo gran notoriedad en la arquitectura doméstica aristocrática a partir del s.lll d.C., circunstancia común a los balnea de otras áreas del imperio (FERNÁNDEZ et alii, 2004). La disposición de este elemento dentro de la vivienda pretendía reafirmar la condición social y económica del propietario. Este hecho es claramente constatable en la Domus / del barrio de las termas de Bilbilis, en el que su dueño cuenta en su casa con un balneum privado, cuando al otro lado de la calle se localizaban unas termas públicas (MARTíN-BUENO et alii, 2007) ${ }^{16}$.

Desde finales del s.IIl y principios del s.IV, los balnea adquieren un papel protagonista, asociados a importantes villae (GARCIAENTERO, 2005-2006). Es el momento en el que se reforman antiguas termas y se construyen los balnea domésticos más monumentales (GARCÍA-ENTERO; ARRIBAS, 2000), cuya presencia era excepcional en las centurias anteriores No obstante, en el s.IV, se identifica también un proceso de abandono de muchos balnea, sin llegar a sustituirse por nuevas termas. Estos espacios comienzan a transformarse y cambia su funcionalidad, destinándolos a diversos usos ${ }^{17}$. La destrucción y abandono de las infraestructuras hidráulicas de abastecimiento en época tardorromana, ha traído consigo la pérdida de la función de los complejos termales. Sin embargo, algunas ciudades siguieron manteniendo total o parcialmente en uso su red de acueductos, como Barcino, Valentia, Tarraco o Corduba. En el caso de Valentia, el acueducto se sigue utilizando en época visigoda y perdura hasta el s.Xl. La gestión del agua aportada por estas canalizaciones pasará a ser semi-privada, utilizada por reyes u obispos para abastecer sus palacios o complejos episcopales, aunque seguirán manteniendo el aporte a fuentes y baños para su acceso público (MARTíNEZ, 201l:
128). La presencia de balnea domésticos más allá del s.V, o de las primeras décadas del s.VI, se pueden considerar excepciones dentro de este panorama general, e indican la complejidad de la disolución del mundo romano y la pervivencia de su modo de vida en las élites tardoantiguas (GARCIA-ENTERO, 2005-2006: 62-63). Estas tradiciones, se pueden rastrear incluso en una perduración del culto a las aguas y del termalismo en época visigoda, durante los siglos VI-VII, a través de las fuentes escritas y de elementos arqueológicos (VELÁZQUEZ; RIPOLL, 1992). En Cartago Nova, se halla uno de los casos de termas hispanas que más han perdurado en el tiempo, en este caso hasta el s.Vl, y las fuentes hacen referencia a unas termas que funcionaban en época visigoda en Sevilla (LEÓN, 2006: nota 20). Otro ejemplo se hallaba en Mérida, donde se excavó un balnea que pertenecería a un palacio visigodo de los siglos VI-VII (FEIJOO, 2000), sin embargo, las últimas investigaciones retrasan su cronología hasta época emiral (ALBA et alii, 2009: p. 207). Las reglas de los monasterios visigodos recogen, entre otros aspectos, las normas básicas de higiene y comportamiento relacionados con el baño (ONTALBA, 1995: 802-804), ya que esta costumbre, en los círculos religiosos, perdurará hasta el s.IX (NAVARRO; JIMÉNEZ, 2009: 98).

La paulatina desaparición de la mayor parte de los edificios termales en occidente, a partir del s.IV, genera que haya que buscar la influencia clásica del baño andalusí en el próximo oriente, donde se ha mantenido la tradición de baños públicos desde la antigüedad (KENNEDY, 1985:8). La planta de las termas romanas se modifica y readapta, y se tiende a reducir sus dimensiones. En el s.VI se construyen en Bizancio instalaciones de baños más pequeñas, que tienen más que ver con balnea que con las grandes termas (NAVARRO; JIMÉNEZ, 2009: 98); para ello se reduce el apodyterium ${ }^{18}$ y desaparecen otras estancias como bibliotecas y gimnasios. En el norte de

I6 Encontramos también ejemplos de balnea en varias viviendas de Pompeya, como la casa del Torello, de Obelius Firmus, del Fauno o de Trebius Valens (MARTÍN-BUENO et alii, 2007: nota 14).

17 Está documentada la amortización de los balnea, que se transforman en espacios destinados a finalidades artesanales o industriales, en espacios de culto cristiano, en habitaciones o en zonas de enterramiento (GARCIA-ENTERO, 2005-2006).

18 En relación a las distintas áreas que conforman los edificios termales romanos y su posterior evolución en época islámica, ver: PAVÓN, 1990: 299-3। 8; LLOBREGAT, 1989: 27-29. 
Siria, surge una nueva tipología de baño, que suprime el frigidarium, otorgando una mayor importancia al espacio de recepción (KENNEDY, 1985: 9). Este hecho también se atestigua en la zona occidental del imperio con anterioridad, desde finales del s.III ${ }^{19}$, que evoluciona hacía modelos en el que cobra especial importancia el área fría del complejo, como un lugar donde la élite aristocrática evidencia su rango social y su riqueza (GARCÍA-ENTERO, 2005-2006: 62).

\section{I.2 El origen del baño islámico y su implantación en al-Andalus}

La transformación de estos modelos clásicos es el germen del baño islámico oriental, adoptados por los califas omeyas, tanto en palacios como en núcleos urbanos (LEÓN, 2006: 421). Se conoce una docena de ejemplos de edificios omeyas con función de baños en el s.VIII, asociados a los conocidos "castillos del desierto" (ALMAGRO et alii, 1975: II5) 20. Los baños se caracterizan por presentar una amplia sala, evolución del apodyterium romano, que adquiere un papel de recepción y que en algunos casos (como el de Jirbat al-Mafyar) llegan a alcanzar una gran monumentalidad (ALMAGRO, 1999: 96). Esta sala se relaciona con el aparato representativo del monarca, motivo por el que algunos autores la han identificado como salón del trono (ALMAGRO et alii, 1975: 83). Estos baños son privados, ya que se encuentran en edificios de "ambiente íntimo", para el uso y disfrute de un reducido grupo de personas privilegiadas, como el príncipe y algunos cortesanos (EWERT, 1991: 126). Esta función de legitimación que tenían los baños orientales, pudo ser el principal motivo de su inserción en al-Andalus, a través de personajes de la aristocracia islámica (LEÓN, 2006: 421).

Los baños identificados de uso exclusivamente privado en al-Andalus se pueden encuadrar, a grandes rasgos, en tres grupos: los baños de la realeza, que forman parte del protocolo cortesano y de la exhibición del poder; los baños palaciegos, asociados a las élites y a personalidades de la sociedad, edificados tanto en alcázares como en casas aristocráticas; y los baños presentes en algunas viviendas de arrabal, de cierta entidad, pero que no llegan a alcanzar las cotas de complejidad del grupo anterior ${ }^{2 !}$.

Vinculados con la realeza, podemos citar el baño anejo al Salón de 'Abd al-Rahman III en Madinat al-Zahra' (VALLEJO, 1987; VALLEJO, 2007: 82-83) o el baño Real del Cuarto de Comares de la Alhambra (VILCHEZ, 200I:42-48). En torno a las áreas palaciegas se han documentado baños en casas de personajes del gobierno o que alcanzaron cierta importancia, como el baño anejo a la denominada Vivienda de la Alberca en Madinat al-Zahra', en origen de carácter unipersonal y que posteriormente pasó a ser compartido con la Casa de Ya'far (VALLEJO et alii, 2004: 202-206), primer ministro (hayib) de al-Hakam II. En un momento más avanzado, hacia el s.XIII y s.XIV, en la Alhambra, se puede hacer referencia al baño de la casa principal de la Alcazaba en la Alhambra, el baño del Palacio del Partal Alto, el baño del Palacio de los Abencerrajes, el baño del Palacio del Convento de San Francisco, el baño de la casa del almotacén en el Secano y el baño del Palacio de Dar al-Arusa o Casa de la Novia. Sin salir de la provincia de Granada, en Almuñécar, hay que mencionar el baño del castillo de San Miguel (VILCHEZ, 200I). En la alcazaba de Almería, se hallan los baños de la Reina, que pertenecen al complejo palatino de época taifa (ALCALÁ et alii, 2005) y los baños de la Tropa, cuya cronología relativa apunta al s.XII (GILOTTE et alii, 20।0). En la fortaleza de Albarracín se excavó un baño relacionado con una gran residencia construida en el s.XI

19 El interés por evidenciar la dignitas o condición social del propietario en los balnea domésticos está estrechamente relacionado con la monumentalización de los mismos en época tardorromana (GARCÍA-ENTERO, 2005-2006: 62). Se han documentado ejemplos en complejos hispanos, galos o norteafricanos (GARCÍA-ENTERO, 2005-2006: nota 4).

20 Se pueden citar, entre otros: Qasr al-Musas, 'Amman, Yabal Says, Anyar, Qusayr 'Amra, Jirbat al-Mafyar o Qasr al-Hayr al-Sarqi (ALMAGRO et alii, 1975: I15-1/8).

2 I Todos ellos, como se ha visto, se ubican en el núcleo urbano. En este sentido, no debemos olvidar los baños rurales, en los que aún no se ha profundizado suficientemente (LÓPEZ, 1994: 204). 
(HERNÁNDEZ; FRANCO, 2006). De finales del s.XII es el baño de una de las casas de la alcazaba de Silves (VARELA, 2003: 85-107). Por último, en Murcia, se documentó un baño privado en la intervención desarrollada en la C/ Polo de Medina, fechado en el s.XIII, y que está relacionado con una vivienda situada inmediatamente al sur (POZO, 1991: 80).

En el caso concreto de Madinat Qurtuba, son de sobra conocidas las crónicas de alBayan, que aluden a la presencia de 300 baños en época de 'Abd al-Rahman III, o los 600 de los que habla al-Maqqari durante la etapa de Almanzor (PAVÓN, 1990: 320), cifras que se han considerado exageradas. Las evidencias arqueológicas ha permitido la identificación de varios de ellos, aunque ni mucho menos alcanzando el número al que hacen referencias las fuentes (Lam. I0). Los baños que tradicionalmente se conocían en Córdoba tienen, en su mayoría, un carácter público (MUÑOZ, 1961-62). En el recinto amurallado de la medina se encuentra el bañuelo de la C/ del Duque (hoy C/ Rey Heredia), del que se conserva una habitación abovedada (MUÑOZ, 1961-62). Se ubica junto a la mezquita que se hallaba en el antiguo convento de Santa Clara (LÓPEZ;VALDIVIESO, 200 I: 225-226). A falta de un estudio pormenorizado del baño, y dada su probable relación con la mezquita, se encuadrarían en la segunda mitad del s.X ${ }^{22}$. Más avanzados en el tiempo son los baños de la Pescadería (C/ Cara), fechados en el s.XII y no en época califal como se había venido afirmando (MUÑOZ, 1961-62: 73). Al norte de la mezquita aljama se encuentran los baños de Santa María, en la C/ Céspedes (MUÑOZ, 19611962: 61-68), cuya cronología está muy discutida. Se consideran mudéjares, aunque podrían reutilizar parte del lavatorio septentrional de la mezquita, edificado por Almanzor a finales del
s.X, además de sus infraestructuras hidráulicas (MONTEJO, 1999: 219; 2003: 179). Se desconoce hasta el momento la localización exacta de este lavatorio, pero sí se ha podido ubicar el lavatorio oriental de época de Almanzor (MONTEJO, 1999), excavado hace algunos años en la C/ Magistral González Francés; además de la sala de abluciones de Hisham I, amortizada en la segunda mitad del s.X. precisamente por la ampliación que el propio Almanzor realiza en la mezquita aljama (MARFLL, 1999: 187-189) 23. En la Axerquia hay documentados dos baños: los baños de San Pedro, en la C/ Carlos Rubio, que datan de la mitad del s.XI (MARFlL, 200I: nota 86; 2008), y que estarían relacionados con la mezquita emplazada en la actual Iglesia de San Pedro 24; y los baños de la C/ Ronda de los Mártires, excavados parcialmente en la década pasada y fechados en el s.X (RODRíGUEZ, 2009).

El alcázar andalusí tiene un importante conjunto de baños en su ángulo noroccidental (MARFIL; PENCO, 1997; MARFIL, 2004), en la zona hoy día conocida como Campo Santo de los Mártires. Estos baños, de carácter regio, se edifican durante el califato, sufriendo sucesivas ampliaciones hasta el s.XIII. Así, al conjunto original se le añade en época taifa (s.XI) un salón de recepciones y posteriormente, en el s.XIl, se construye un nuevo baño, momento en que el baño califal dejaría de utilizarse ${ }^{25}$ y se reforma para destinarlo a otros usos (MARFIL, 2004: 64). Dentro del recinto del antiguo alcázar andalusí, pero en época cristiana (1338), Alfonso XI levanta unos baños privados ${ }^{26}$, de estilo mudéjar, para su favorita Leonor Núñez de Guzmán (MUÑOZ, 1961-62: |10-111).

Las intervenciones de los últimos años en la zona de poniente ha documentado varios

\footnotetext{
22 La mezquita se había fechado en época de Almanzor, sin embargo, las investigaciones recientes han retrasado su fecha hasta época de al-Hakam II (LÓPEZ, VALDIVIESO, 200I: 226).

23 Los lavatorios o salas de abluciones (mida'a) no se pueden incluir en el grupo de los baños, pero al estar relacionados con la limpieza ritual preceptiva en la religión musulmana, nos parece adecuado mencionarlos en este recorrido.

24 La iglesia de San Pedro fue en origen la iglesia mozárabe de Los Tres Santos, convertida en mezquita musulmana a mediados del s.XI (MARFIL, 200I: 135).

25 No obstante, se seguirá utilizando el antiguo horno y la caldera de época califal (MARFIL, 2004: 64).

26 El monarca había prohibido los baños públicos por razones de moral (MUÑOZ, 196।-62: I I0).
} 
baños, algunos de ellos relacionados con esas grandes propiedades o fincas de recreo que, generalmente, se han identificado como "almunias" 27, que en Córdoba tienen su origen en al-Rusafa, la residencia construida por el emir 'Abd al-Rahman I en la falda de la sierra (MURILLO, 2009; MURILLO et alii, 20I0a: 565-586). Es el caso de tres baños hallados en la zona meridional del arrabal oeste, que se encuentran a poca distancia entre sí: los baños de la Ronda Oeste (CAMACHO, 2002), los baños de El Fontanar (BERMÚDEZ et alii, 2004) y los baños de la C/ Fontanar de Cábanos (APARICIO, 2002). Dos de ellos (Ronda Oeste y El Fontanar) se sitúan en el interior del recinto de la almunia, lo que indicaría su condición de privados ${ }^{28}$. Estos baños son interesantes desde dos vertientes: por un lado, permite avanzar en el conocimiento de las distintas partes que conforman estas viviendas de tipo palaciego; por otro, aportan importantes datos al estudio de los baños de época emiral. En este sentido, la almunia de El Fontanar se edifica en el s.IX (BERMÚDEZ et alii, 2004), mientras que la almunia y los baños de la Ronda Oeste generan más controversia, ya que se fija su construcción en el s.X (CAMA$\mathrm{CHO}, 2002$ ), aunque otros autores creen que habría que adelantar esta fecha hasta el s.IX (MURILLO et alii, 2004: 266-267; 20 I0b: 539-540). El otro ejemplo, en la C/ Fontanar de Cábanos, se halla a pocos metros de otra gran residencia, documentada en la ampliación del Hospital Reina Sofía (CASAL, 20I0). En esta ocasión, los baños se han determinado como públicos ${ }^{29}$, datándose en el s.X.

En el sector septentrional del arrabal occidental, en el Yacimiento Arqueológico de Cer- cadilla se excavaron dos baños. Uno, que denominamos baños de Cercadilla (FUERTES et alii, 2007: 186-194), se encuentra junto a la puerta de acceso al conjunto tardorromano (HIDALGO, 2007) y tienen un uso público. Su construcción se ha planteado durante época emiral, dada sus características edilicias ${ }^{30}$. El otro baño se encuentra en la Casa 25 del arrabal califal de Cercadilla (FUERTES, 2007: 58-59). Se trata de un baño particular, y su interés radica en que cuenta unas características urbanísticas similares al caso que nos ocupa, por lo tanto, volveremos a él más adelante.

En general, los baños que se han identificado como privados presentan variaciones tanto en su morfología como en su monumentalidad y riqueza, relacionada estrechamente con la condición económica y social de su propietario (NAVARRO; JIMÉNEZ, 2009: 109). De todos sus elementos, el que siempre se encuentra presente es la zona caliente, independientemente de las dimensiones que tenga. Las plantas parten desde una sala con una pileta y un hipocausto, alimentado por un horno, como es el caso del baño de la Casa 25 de Cercadilla (FUERTES, 2007), hasta otras que cuentan con todas las áreas de un baño público, como el baño del alcázar andalusí de Córdoba (MARFIL, 2004), que incluso incorpora una sala que evoca los espacios de recepción de la arquitectura omeya oriental (LEÓN, 2006: 42I).

El baño que a continuación analizaremos se encuentra en una casa de generosas dimensiones, pero en ningún caso se puede equiparar a las residencias palaciegas o a las grandes residencias construidas en el suburbio de la ciudad.

27 Se trata de complejos edificios que pertenecen a las élites, estructurados en varios sectores de representación, con diversas estancias en torno a patios de gran tamaño. Estas edificaciones, que actúan como elemento de atracción, generan a su alrededor una progresiva actividad constructiva que tiene su momento más álgido durante el califato, con la urbanización de extensas áreas de arrabal (MURILLO et alii, 2004; 20I0b).

28 En ambos casos, en las inmediaciones de los baños se encuentra una mezquita (LUNA, ZAMORANO, 1999; CAMACHO, 2002) y un cementerio (CASAL et alii, 2006: 276-277). La relación entre estos elementos se ha documentado en otras zonas, como Murcia y Palma de Mallorca (ROBLES et alii, 1993).

29 Su uso público se ha determinado por un espacio al este del baño, interpretado como una gran sala con pilas para abluciones (APARICIO, 2002).

30 La precisión cronológica no ha sido posible a causa de problemas metodológicos (FUERTES et alii, 2007: nota I6; nota I8). Se interpreta que la sala absidiada seguiría los modelos de la arquitectura termal clásica (romana y bizantina), e incluso estaría influenciado por el edificio tardorromano (FUERTES et alii, 2007: 198; nota 25). Su construcción se habría llevado a cabo por la población mozárabe, que durante el emirato habitaba esta zona de la ciudad (FUERTES et alii, 2007: 198-200). 
Sin duda alguna, se trata de un elemento poco frecuente en las viviendas andalusíes ubicadas en arrabales, como demuestra el hecho de que este caso es el único en el que una casa contara con un recinto de estas características en el solar, a pesar de que algunas tenían mayor superficie y complejidad.

\section{LA VIVIENDA}

Se encuentra emplazada en la manzana norte de la parcela (Fig.2), a la que se accede a través de una de las vías principales que articula este sector de arrabal. Esta calle estaba pavimentada con grava de pequeño tamaño compactada, mezclada con fragmentos cerámicos, arena y cal, y alcanzaba una anchura de 8,20 metros. En planta (Fig.3), la casa presenta una tendencia rectangular, que se rompe en el ángulo nororiental por la disposición del baño, que se encuentra desplazado con respecto al eje del resto de la vivienda. La superficie estimada, incluido el baño ${ }^{31}$, es de $243,10 \mathrm{~m}^{2}$, de los que se han excavado $176,50 \mathrm{~m}^{2}$. Se pueden distinguir, dentro de la casa, dos ámbitos diferenciados, articulados cada uno en torno a un patio: por un lado, un área de acceso y servicio; y, por otro, un área residencial principal, desde la que se accede al baño.

\section{I El área de acceso y servicio}

Este núcleo es del que se ha obtenido menos información, al haberse documentado parcialmente (Fig.3: 10). Es la zona de la vivienda más cercana a la calle, y se organiza en dos crujías en torno al patio. Al sur se encontraba la crujía a la que se accedía desde la calle, de la que sólo se excavó una pequeña parte de uno de los espacios que la formarían, de apenas $90 \mathrm{~cm}$ de ancho (Lam.2A). Comunicaba con el patio a través de un vano situado en el ángulo noreste, que cerraba con una puerta de una hoja, como indica la quicialera tallada en el umbral. Al interior, la habitación tiene un pequeño escalón, ya que su cota es inferior a la del patio. Desconocemos la funcionalidad de esta pequeña estancia, pero podemos descartar que se destinara a letrina, por la ausencia de las losas de la estructura de evacuación y de pozo negro en la calle. Del resto de espacios que formarían esta crujía no se excavó nada. Si la hipótesis de reconstrucción de la vivienda es correcta, en esta zona, además de la habitación documentada, se debería hallar el zaguán y alguna otra dependencia.

Desde la crujía sur se ingresa en el patio (Fig.3: 9), que tiene planta rectangular y una superficie de 20,75 $\mathrm{m}^{2}$. Se encuentra desplazado hacia el lateral oriental de la casa, adosado al cierre este. Se pavimenta con losas irregulares de caliza micrítica en la mitad oeste, completado en el resto con cantos rodados y guijarros de diverso tamaño (Lam.2B). En la zona central del pavimento se halló una depresión en el firme, colmatada por sillarejo de areniscas procedentes del desplome de los muros. Podría tratarse de un pozo de abastecimiento de la vivienda, que tras el abandono se rellenó con el material derruido de los paramentos.

El patio permite el paso a la crujía oeste (Fig.3: 5 y 8), donde se ha documentado parte de la superficie de dos espacios (Lam.2C). Al sur, se halla una habitación que comunicaría directamente con el patio, a través de un vano que no se ha conservado, al estar completamente arrasado el muro. Es posible que también pudiera conectar con la crujía sur, pero no se ha podido comprobar arqueológicamente. Esta estancia se pavimentaba con losas de calcarenita dispuestas en perpendicular al muro del patio. El otro espacio de la crujía oeste se encuentra al norte, y se trata de una habitación con un pavimento de baldosas cuadradas de barro cocido. Entre las dos estancias de la crujía, debe-

31 No se excavó la totalidad de la superficie de la vivienda, lo que dificulta la interpretación de algunos espacios constructivos. Parte de la crujía sur que conectaba con la calle se encontraba bajo la zona central del solar, que no se iba a ver afectada por la nueva edificación. El cierre occidental de la casa quedó soterrado por un corredor que no se intervino para facilitar el acceso de maquinaria al centro de la parcela. Se ha realizado una reconstrucción hipotética de la totalidad de la planta de la vivienda, utilizando para ello la extensión que se han excavado. Esta propuesta deberá ser corroborada o descartada por los resultados que arroje el seguimiento arqueológico. 
ría haber una puerta que no se ha detectado, ya que puede que se encuentre en la zona que no se intervino. En su muro septentrional tiene un vano desde el que se accede al área residencial principal. Esta puerta se ha excavado de forma parcial, aunque su ancho se establece en torno a un metro. Con los datos obtenidos hasta el momento, no se le puede asignar una funcionalidad a estos espacios de la crujía oeste, pero es factible que actuaran como conexión entre los dos ámbitos de la casa.

\subsection{El área residencial principal}

Es la zona más reservada de la vivienda, cuyo elemento central es un patio (Fig.3: 4). Se ingresa desde el vano situado en la esquina suroeste. Este patio es de mayores dimensiones que el del área de servicio, con una superficie excavada de 45, $10 \mathrm{~m}^{2}$, aunque se estima que alcanzaría los 58,36 m² (Lam.3A). Articula una crujía al norte y otra al sur, además de las instalaciones que pertenecen al baño privado, al que se entra desde una puerta ubicada en su ángulo nororiental. Los muros que delimitan el patio presentan una fábrica con zócalo de sillares de calcarenita, dispuestos en el paramento norte a tizón; en el este, alterna sillares a soga con mampuesto; $y$ en el cierre sur se utilizan sillares cuadrados. Sobre este zócalo, se levanta el resto del muro, realizado con tapial.Tiene andén perimetral, al menos en tres de sus lados ${ }^{32}, y$ muestra dos técnicas edilicias: una para los lados este y sur, y otra para el lateral norte, donde se encuentra la crujía principal. El andén este y sur está realizado con una hilera de baldosas cuadradas de barro, trabadas entre sí con una fina capa de cal. Se remata hacía el interior con otra hilera, esta vez a base de losas rectangula- res de calcarenita, unidas por sus lados cortos y apoyadas sobre una cimentación de pequeños cantos rodados y guijarros. Esta tipología de andén solo se documentó en esta vivienda del arrabal ${ }^{33}$. El andén norte tiene una fábrica más común, con losas de calcarenita dispuestas perpendiculares al muro de cierre, trabadas por sus lados largos. Cuenta con un mayor desarrollo en anchura con respecto al andén este y sur, sin duda un recurso constructivo que permite destacar la importancia de las habitaciones de esta crujía septentrional. El andén occidental se encontraría bajo la parte sin excavar. En las dos esquinas del andén oriental se halló sendas oquedades, que perforaban la piedra y en el que se embutían dos piezas cerámicas (alcadafes), de los que quedaban los restos del situado en el ángulo noreste. La pieza no presentaba conexión alguna con otros elementos, aunque podría recibir el agua de los canalones del tejado, evitando con ello que se erosionara el andén o el pavimento sobre el que vertería el agua recogida del tejado ${ }^{34}$. El espacio central del patio se pavimentó con tierra batida mezclada con picadura de arenisca. Es reseñable la ausencia de pozo de abastecimiento en el patio. En ningún momento nos planteamos que esta casa no tuviera esta infraestructura, por lo que, o bien se halla bajo la cota de excavación 35 , o bien se encuentra en el otro patio, como ya se ha comentado.

La crujía sur (Lam.3C) ocupa una superficie de $14,30 \mathrm{~m}^{2}$, y se entra desde el patio mediante una puerta de doble hoja, de un metro de anchura. Se conservaba el arranque de las mochetas y las dos quicialeras, una tallada en una pequeña losa de caliza y la otra en un fragmento de arenisca. El vano se encontra-

32 A pesar de que no se ha excavado el cierre occidental del patio, los datos obtenidos en el resto del patio nos lleva a pensar que contaría con andén oeste, probablemente con una fábrica similar al del lado sur y este.

33 Los andenes que se han hallado en los patios de las casas excavadas están realizados, por regla general, con losas de calcarenita. Puntualmente se detectó un andén realizado con una fábrica de menor calidad, con cantos rodados. Los andenes están asociados en todos los casos a patios con pavimentos terrizos, ya que permitían el paso de una estancia a otra de la vivienda sin tener que atravesarlo por el centro, que en los días de lluvia se encontraría embarrado.

34 Se halló una pieza parecida en otra de las viviendas. Ejemplos similares se han documentado en casas de Murcia, con la diferencia de que se embuten en el suelo del patio y no en el andén, además están conectadas con canalizaciones que evacuan el agua bajo el andén, actuando como piletas de decantación (IIMENEZ, NAVARRO, 2002: 477).

35 Es muchos casos, los pozos se hallaban bajo los derrumbes de los propios encañados, y se han detectado al realizarse el seguimiento de la obra posterior (VÁZQUEZ, 2010: 644). 
ba pavimentado con losas rectangulares de calcarenita y, a interior, no presentaba suelo de obra, pero en la colmatación, se hallaron varias baldosas de barro, que pudieron pertenecer al firme de la habitación. En principio, la crujía estaba formada por una sola estancia, tal y como indica la ubicación centrada de la puerta con respecto al muro (Fig.3: 6). Se trataría de un salón secundario, enfrentado al que se encontraba en la crujía norte, aunque de menores dimensiones. Posteriormente, se construye un tabique que compartimenta el espacio, y define una pequeña estancia en el lateral oriental de apenas $90 \mathrm{~cm}$ de ancho, y que se puede identificar como una alcoba (Fig.3: 7). Bajo la puerta de entrada a esta crujía sur, procedente del patio principal, se detectó una canalización, que recorría toda la habitación en diagonal, de noroeste a sureste, para continuar hacía el patio del área de servicio y la esquina suroriental de la casa. Sólo se halló el tramo que discurría por el salón secundario. La canalización estaba fabricada con mampuesto de pequeños nódulos de calcarenita y caliza, a los que se trababa con una argamasa de arcilla y cal. La sección era rectangular y se encontraba protegida por una cubierta, fabricada con losas irregulares de caliza, unidas entre sí por sus lados largos y sin trabazón de ningún tipo.

En la crujía norte se hallaba el salón principal de la vivienda (Lam.3B), al que se accede mediante una puerta de 1,25 m de ancho, dispuesta en el centro del muro, que se cerraba mediante una doble hoja, como indica la presencia de una quicialera tallada en un pequeño fragmento de caliza junto a la jamba oriental. En el lado oeste habría otra quicialera, que no se ha conservado. Al interior, el salón (Fig.3: I) tenía una superficie excavada de $16,54 \mathrm{~m}^{2}$, pero se estima que en total alcanzaría hasta $22,60 \mathrm{~m}^{2}{ }^{36}$. Los muros estaban realizados con tapial, apoyado sobre un zócalo de sillares de calcarenita. El arrasamiento del alzado de tapial en el muro que limita con el patio, ha permitido comprobar cómo los sillares del zócalo, al menos en este lienzo, estaban dispuestos a tizón, con excepción de los sillares que enmarcaban la puerta, que en este caso tenían forma cuadrada. Una vez en el interior del salón, las paredes se revisten con un enlucido a base de mortero de cal, sobre el que se aplicaba pintura a la almagra. Todo el espacio se pavimentó con baldosas cuadradas de barro, conservadas en mayor medida en la mitad norte de la estancia. En algunas zonas, el suelo se encontraba arrasado, lo que permitió observar la cama sobre la que se asentaba, fabricada con una capa de mortero de cal, que aún tenía la impronta de las baldosas. Junto a la puerta, una serie de baldosas contaban con unas dimensiones menores, sin duda relacionadas con reformas, debido al desgaste por su uso continuado. Al este del salón principal, se dispone un tabique que lo separa de una alcoba lateral (Fig.3: 2), a la que se entra a través de un vano de I,25 metros. El vano no contaba con ningún sistema de cierre, ya que lo que se pretendía era simplemente definir dos espacios que estaban relacionados. La superficie de la alcoba era de $6 \mathrm{~m}^{2}$, y tenía las mismas características constructivas del salón: paredes enlucidas con mortero de cal a la almagra y suelo pavimentado con baldosas cuadradas apoyadas sobre una cama de cal.

En este ámbito eminentemente privado de la vivienda es donde se encuentra el baño, cuya entrada se realizaba desde una puerta situada en la esquina noreste del patio.

\section{EL BAÑO}

El recinto destinado al baño ocupa una superficie de 50,70 $\mathrm{m}^{2}$, con planta trapezoidal y un chaflán en el ángulo sureste (Fig.4 y 5). Un espacio central articula todo el conjunto, en torno a la que se disponen todas las salas. Se encuentra a una cota inferior en relación al resto de la vivienda, llegando a un desnivel con el andén del patio de $50 \mathrm{~cm}$. El baño está formado por las siguientes dependencias: sala central, letrina, salas anejas, sala caliente y sala del horno (Lam.4).

\footnotetext{
36 La puerta de acceso a los salones se dispone generalmente en el centro del muro. Esto ha posibilitado establecer las dimensiones totales de la estancia, y a su vez ha permitido plantear la ubicación del muro limítrofe occidental de la casa, situado en el área sin excavar.
} 


\section{I Entrada}

El acceso al complejo se realiza desde el patio del área residencial, mediante un vano de $90 \mathrm{~cm}$ de anchura, algo más estrecho que el resto de los hallados en la casa (Lam.5A). Se cerraba mediante una puerta de doble hoja, lo que permitía aislar el baño del resto de la vivienda y evitaba la pérdida de calor de su interior. En el piso se conservaban las dos quicialeras de las hojas de la puerta, una tallada en un sillar de calcarenita y otra en un trozo irregular de caliza. Para salvar el desnivel existente entre la cota del andén del patio y el interior del recinto, se dispone un escalón tras atravesar la luz de la puerta, formado por un sillar rectangular de arenisca.

\subsection{Sala central}

Al interior, las distintas estancias que conforman el baño se hallan estructuradas en torno a un espacio que hemos denominado sala central (Fig.4: I), desde la que se permite la comunicación con todas las habitaciones: al norte se encuentra la sala caliente, al este la letrina y la sala del horno, y al sur las dos salas anejas. La planta de esta estancia es rectangular, y tiene una superficie de 17,16 $\mathrm{m}^{2}$. Se pavimenta con losas rectangulares de calcarenita, orientadas según las necesidades del espacio a cubrir (Lam.5B). Una de las losas cumplía, además, la función de tapa de un pozo negro que se encontraba dentro de esta sala y que recibía los vertidos de la letrina situada inmediatamente tras el tabique oriental.

No es posible la identificación de esta sala con algunas a las estancias que se encuentran en el baño público. Este espacio es un claro ejemplo de la adecuación del modelo de hammam al contexto privado, limitado por la superficie de la que dispone. En este caso, no se han dispuesto las tres áreas del baño (seca, húmeda y de servicio) de forma independiente, ya que las dimensiones no lo permite. La solución adoptada, sin renunciar a ninguna de las estancias necesarias para el ritual del baño, es utilizar la sala central como zona de acceso a todas ellas, maximizando de esta forma el espacio con el que cuenta. Además, en este punto confluyen los vertidos de agua, que provienen tanto de la letrina como de la sala caliente, para su posterior evacuación.

\subsection{Letrina}

Se ubica en la crujía este del baño (Fig.4: 5), con planta trapezoidal debido a su adaptación al muro oriental del recinto, $y$ tiene una superficie de $3 \mathrm{~m}^{2}$. Para ingresar es necesario subir un pequeño escalón, de unos $10 \mathrm{~cm}$, que salva el desnivel con la sala central. El vano posee una anchura de $90 \mathrm{~cm}$ y no se han hallado indicios de que contara con puerta para su cierre. Se encuentra enfrentado con la entrada al baño desde el patio, por lo que para proporcionar la intimidad necesaria, la letrina propiamente dicha se encuentra dispuesta en recodo, evitando de esta forma que sea visible desde el exterior. Al interior, hay a un corto pasillo, de apenas I metro de longitud, separado de la letrina por un tabique de tapial, conservado en su arranque y que se estrecha hacía el interior de la estancia. Se reviste en su cara sur con un enlucido de mortero de cal. La estructura de la letrina estaba realizada con dos losas paralelas de calcarenita, de la que sólo se ha conservado la septentrional, elevadas con respecto a la cota del suelo y con un hueco entre ambas para la zona de vertido (Lam.6). Éste se realiza a un desagüe, fabricado con sillares de calcarenita, con una acusada pendiente que facilitaba la evacuación hacia el pozo negro situado bajo el suelo de la sala central. Para facilitar la limpieza de este espacio, se pavimentó con un suelo de losas rectangulares de arenisca.

\subsection{Salas anejas}

La crujía sur del baño cuenta con dos habitaciones de desigual tamaño, una al oeste y otra al este, a las que se entra desde la sala central (Lam.4). Son las estancias que se hallan más distantes de la sala caliente. La sala aneja oeste (Fig.4: 6) tiene planta rectangular, con $5,98 \mathrm{~m}^{2}$ de superficie. Se ingresa por medio de una puerta de I, 15 metros de anchura, que se cerraba con dos hojas, tal y como indican las quicialeras halladas en cada uno de los extremos del vano, ambas talladas en piedra caliza. Es la única sala de toda la instalación que no 
cuenta con un suelo de fábrica, ya que en este caso, se pavimenta con tierra batida, a la que se le ha añadido guijarros de pequeño tamaño y fragmentos cerámicos.

La sala aneja este (Fig.4: 7) es un espacio de reducida superficie, apenas con $2,71 \mathrm{~m}^{2}$ y planta ligeramente trapezoidal. Se accede por un vano muy estrecho, de $55 \mathrm{~cm}$, situado junto a la entrada de la letrina. Para el suelo de esta habitación se utilizaron losas rectangulares de calcarenita, de similar factura que las de la sala central y la letrina. Estas estancias tendrían una función auxiliar dentro del baño, y se podrían haber utilizado de habitaciones de reposo o vestidores.

\subsection{Sala caliente}

Se trata de la sala que define la funcionalidad de todo el recinto, situada al norte, en una posición centrada (Fig.4: 2 y 3). Está formada por la estancia propiamente dicha y una pileta. Para acceder a su interior es necesario recorrer un corto pasillo desde la sala central, ubicado en el ángulo noroccidental de ésta. El pasillo, que tiene 3,40 metros de longitud y I,80 metros de anchura, acaba en un pequeño recodo para encarar el vano de la sala caliente. Ésta presenta la cota más elevada de todas las estancias que componen el baño. Por tanto, para superar la diferencia de cota con la sala central, cifrado en unos $30 \mathrm{~cm}$, es necesario subir un pequeño escalón de unos $10 \mathrm{~cm}$ para ingresar en el pasiIlo, que, además, tiene una ligera pendiente que permite alcanzar la cota de la sala caliente. La pared oeste y norte se encontraban enlucidas con mortero de cal. El pavimento del pasillo es de losas de calcarenita, conservadas únicamente en su tramo inicial, ya que en el resto del recorrido sólo ha permanecido la impronta sobre la cama de cal. El vano de la sala caliente tiene escasamente $70 \mathrm{~cm}$, y no se hallaron elementos constructivos que pudieran verificar la presencia de una puerta para cerrarla; no obstante, esta zona sufrió un acusado arrasamiento, por lo que no se podría descartar.
La planta de la sala caliente es cuadrada (Lam.8), y su superficie es de 3,90 $\mathrm{m}^{2}$. Por debajo del nivel de suelo se encuentra el hipocausto (Fig.6), formado por un perímetro de ladrillos adosados al interior de los muros de la habitación ${ }^{37}$ y, en el centro, se levantan dos pilares rectangulares, también fabricados con ladrillos y exentos al perímetro, que favorecería el libre recorrido del aire caliente y la sustentación del pavimento de la sala. Sobre la estructura de la cámara de aire se dispone la cama del suelo, realizada con una gruesa capa de mortero de cal mezclada con guijarros y fragmentos cerámicos, lo que le otorgaría la resistencia necesaria para soportar el firme. Sobre esta preparación se hallaba el pavimento de la estancia, realizado con un enlosado de baldosas cuadradas de barro cocido, a tenor de los escasos fragmentos que permanecían in situ. Al igual que el suelo, el estado de conservación de la cama era muy precario, arrasada parcialmente en varias zonas. Esto permitió la excavación de parte del hipocausto y su posterior documentación. Con respecto a las características de los muros de la sala, se ha conservado solamente el arranque de éstos, formados por sillares de calcarenita, dispuestos tanto a soga como a tizón, sin seguir un orden aparente. En el muro oriental se encuentra embutido el arco del horno. El muro norte conserva restos de revestimiento con mortero de cal, continuando el enlucido que se encuentra en el pasillo. Resulta interesante que, para reforzar el muro septentrional de la sala caliente, se dispone en su base una serie de ladrillos que apoyan sobre el alzado de la pared, a modo de pequeño zócalo, que posteriormente se revestirían con el enlucido parietal. Esto suponía el refuerzo del paramento, ya que si bien se levantaba sobre un cimiento y un primer tramo de zócalo de una considerable consistencia, el resto del alzado era de tapial. En el muro meridional se encuentra el vano que permite el paso al interior de la pileta. Se documentaron una serie de ladrillos embutidos en la piedra, en un tramo de $65 \mathrm{~cm}$ de longitud, que se caracterizan por tener la misma cota que el pavimento de la sala caliente y por

\footnotetext{
37 Un chapado perimetral de ladrillo al interior de los muros se documentó en el hipocausto de los baños anejos al Salón de 'Abd al-Rahman III, en Madinat al-Zahra' (VALLEJO, 1987: |43).
} 
situarse en una posición centrada en relación al eje de la pileta.

La planta de la pileta es rectangular (Lam.9), de $90 \times 85 \mathrm{~cm}$. Su fábrica utiliza las losas de arenisca, paralelas y dispuestas sobre su canto, para levantar las paredes. Al interior, adosado a su lado norte, se dispone un escalón de $40 \mathrm{~cm}$ de altura, a modo de banco. Toda la estructura se encuentra revestida al interior con mortero hidráulico, necesario para su impermeabilización. Para el suelo se optó por un pavimento realizado con dos grandes losas irregulares de caliza micrítica. La evacuación del agua de la pileta se efectuaba por medio de una tubería de plomo ${ }^{38}$, empotrada en la base de la pared sur ${ }^{39}$. La pileta podría contener agua caliente o tibia, produciendo un contraste de temperatura para refrescar. Esto propicia la inmersión del cuerpo, hecho muy habitual en el mundo romano con amplias piscinas y que en los baños árabes quedaban reducidas a meras albercas en el mejor de los casos (SALVATIERRA et alii, 1993: 51), cuya finalidad no era sumergirse. De ellas se extraía el agua con un balde para lavarse y enjabonarse (NAVARRO; IIMENEZ, 2009, 1 17). No obstante, la presencia del escalón en el interior de la pileta parece indicar la inmersión parcial ${ }^{40}$.

\subsection{Sala del horno}

Ocupa la mayor parte de la crujía oriental del baño (Lam.7). En planta, su forma es rectangular (Fig.4: 4), y abarca una superficie de $9 \mathrm{~m}^{2}$. Su puerta está situada en el ángulo suroeste, a través de un vano de $80 \mathrm{~cm}$, al que se accede desde la sala central. Debido al arrasamiento de la pared oeste, donde se hallaba la entrada, no se recuperaron restos de quicialeras o mochetas in situ, que demostrara la presencia de una puerta que permitiera el cierre. Sin embargo, en la colmatación estaba presente un fragmento de piedra caliza con un quicio tallado, y dadas las características de este tipo de espacios, donde la combustión del horno produciría cantidades elevadas de humo, es necesario una puerta que permitiera aislarla del resto de las habitaciones del baño y de la vivienda. No solamente los muros sufren la pésima conservación, ya que el suelo también estaba afectado. En el extremo sur del muro este se detectaron una serie de baldosas cuadradas de barro cocido, trabadas entre sí con una capa de cal muy fina. Algunas de ellas, estaban adosadas a unas losas de calcarenita junto al cierre sur, que a la postre resultaron tratarse del suelo de la letrina, que se adentraba en la sala del horno. Este es el único indicio de la presencia de un suelo de fábrica en este espacio. Bajo este nivel, cuya cota era similar a la de la letrina y de la sala central, se encuentra una potente nivelación, utilizando para ello arenas mezcladas con fragmentos cerámicos, cantos rodados de tamaño medio y nódulos de caliza.

El horno (Fig.6), destinado a calentar el hipocausto situado bajo la sala caliente, se ubica al fondo de la estancia, en el extremo norte, permitiendo que el resto de la habitación pudiera utilizarse para el almacenamiento de la leña que se usaba como combustible. El horno estaba orientado hacia la sala caliente, perpendicularmente a ésta. Estaba construido con fábrica de ladrillo, mediante dos paredes paralelas que definían una cámara de combustión rectangular (con dimensiones de $1 \times 0,45$ m), donde se depositaba la leña o el carbón. La pared sur del horno se hallaba parcialmente desmontada, con cinco hiladas de ladrillos menos con respecto a la pared norte. Sin duda, su cercanía al sector de mayor arrasamiento, ha propiciado su destrucción. Al interior, la cámara de combustión estaba colmatada por una capa de ceniza en su base. Entre los restos se hallaron pequeños fragmentos de cerámica

38 El empleo del plomo en los conductos del agua se utilizaban como símbolo de riqueza del dueño, a pesar de que se sospechaba que podía ser perjudicial para la salud (REKLAITYTE, 2007: 160-161).

39 No se ha podido establecer la trayectoria que sigue la tubería hasta su evacuación. El elemento más cercano para verter el agua es el pozo negro de la letrina, pero hasta que no se desmonte el pavimento de la sala principal, no se podrá documentar el recorrido de este desagüe.

40 Un claro ejemplo de baño por inmersión se encuentra en los baños del Salón de 'Abd al-Rahman III, donde al norte de la sala caliente se ubica una saleta con una bañera destinada para ese fin (VALLEJO, 1987: |44-|45). 
y algunos huesos de aceituna. Bajo la ceniza, se documentó un estrato arcilloso, con restos de ladrillos quemados, que pertenecerían a la base de la cámara de combustión. En el muro oeste, que limita con la sala caliente, se embute el arco del horno, permitiendo de esta forma el paso del calor producido hacía el hipocausto. Este arco es de medio punto, con $70 \mathrm{~cm}$ de altura desde el suelo de la cámara de combustión hasta la clave del arco y, al igual que el resto del horno, para la construcción de sus dovelas se usa el ladrillo.

En el funcionamiento general del sistema de calefacción queda una cuestión importante por resolver, que es la ubicación de las toberas que permitieran el tiro del horno y la eliminación de humos. La disposición de las chimeneas se establece, normalmente, en los ángulos de la sala caliente, empotradas en la pared (NAVARRO; JIMÉNEZ, 2009: I 16), pero en este caso no se ha detectado evidencia alguna de la presencia de elementos que circulara el aire caliente hacía el exterior de la vivienda. Tampoco hay restos de una posible caldera, para crear vapor de agua al calentarla con el hogar del horno. La escasa conservación en altura del muro medianero entre la sala caliente y la sala del horno, tampoco permite vislumbrar si disponía de uno o varios orificios que traspasara el vapor al interior de la sala caliente.

\section{CONTEXTO URBANÍSTICO}

El sector donde se inserta la vivienda del baño se caracteriza por la presencia de casas de importantes dimensiones, tal y cómo se ha podido comprobar en la intervención (Fig.2) Se trata, como se ha señalado con anterioridad, de una manzana encuadrada entre una calle principal al sur y una importante vía de comunicación al norte, como es el Camino Viejo de Almodóvar.

\section{I El baño en su entorno urbano}

En la zona del arrabal donde se ubica el baño se aprecia una subdivisión de grandes casas en otras de dimensiones menores ${ }^{41}$, aunque hay algunas que siguen conservando una extensa superficie ${ }^{42}$. Esto plantea la cuestión del momento de la construcción del baño, es decir, si se realiza cuando se construyen las viviendas originales, o por el contrario, es el resultado de una reforma posterior del parcelario. En este sentido, pensamos que el baño es una construcción posterior. En primer lugar, la instalación se sitúa desplazada del eje de la vivienda, quedando como un apéndice de ésta. Su alineación coincide con la de la casa 10 , pero se encuentra totalmente aislado de ella, sin que haya ningún tipo de comunicación. El elemento que define la transformación del parcelario en esta zona es un muro de gran longitud, orientado noreste-sureste, que divide este sector hasta la calle. Se trata, además, del límite oriental del baño, que en su recorrido, quiebra a la altura de éste, generando un chaflán. Así, por ejemplo, junto a la casa 9 forma un espacio entre él y la alcoba sur, que queda inutilizado dadas sus escasas dimensiones. En la casa II, obliga a realizar una estancia con planta poligonal para, de esta forma, adaptarse al quiebro que presenta. La edificación del baño está asociada a la del muro, y está obligada a organizar su espacio condicionado por éste, como se observa en la planta de la estancia destinada a letrina o en la sala del horno. El otro indicio que plantea la construcción del baño a posteriori es la situación del pozo negro de la letrina, dentro de la sala central (Lam.6). Los malos olores que producen los pozos y la necesidad de limpiarlos periódicamente (REKLAITYTE, 2008: 340-341) aconsejan su ubicación en zonas ventiladas y de fácil acceso. Generalmente, en los arrabales cordobeses, los pozos negros se realizan en la calle junto a la fachada de la casa, en la zona donde se sitúa la letrina, para

4 I La casa 2 y la casa 3 son el resultado de la división de una sola, al igual que ocurre en el caso de la casa 4 y 5 . Está constatado arqueológicamente por la presencia de muros divisores con una orientación distinta al resto, y por hallarse el mismo pavimento en espacios que pertenecen a viviendas distintas. Además se aprecia continuidad, de una casa a otra, de los paramentos que delimitan las crujías, a pesar de hallarse separados por el nuevo muro divisor.

42 En especial destaca la casa I, de la que se ha excavado un gran patio, con una alberca y un pozo con brocal de piedra de planta octogonal, que comunica a través de un pasillo en recodo con otro patio secundario, que cuenta también con un pozo. 
recibir el vertido directamente (MURILLO et alii, 1999: 148). Así se ha comprobado, también, en las excavaciones realizadas en el arrabal donde se halla la vivienda (VÁZQUEZ, 20 I0: 649-650). Por tanto, la construcción del pozo en el interior de la sala central estaría obligada por la transformación del parcelario original, al quedar la superficie destinada al baño embutida entre el caserío circundante, muy alejado de una calle o un adarve donde poder evacuar el agua de la letrina.

Para edificar el baño en un entorno que se encontraba habitado con anterioridad, se debió llegar a un acuerdo entre el propietario y los dueños de las casas adyacentes, ya que linda con varias viviendas. Así, se requiere el permiso de los demás vecinos, que pueden vetar su construcción si reciben algún perjuicio, como la excavación de un pozo (que podría afectar a su suministro de agua) o la instalación de una letrina cerca de los muros medianeros. Además, su funcionamiento produce, entre otras cosas, una gran cantidad de humo procedente del horno, que puede llegar a afectar al resto de residentes (VIDAL, 2000: 104). Para ello, las ordenanzas de Córdoba y Sevilla preveían que la construcción de estos edificios se debía realizar sin molestia para los vecinos, y se debían blanquear periódicamente terrazas y paredes, y almacenar la leña - la paja utilizada de combustible en el interior de la vivienda (PAVÓN, 1990, 345). Los hornos de los baños era una cuestión que preocupaba a los juristas, porque provocaban daños a la vista y ruidos, además de riesgo de incendio por las chispas (REKLAITYTE, 2006: 244-245).

Los materiales empleados para la construcción del baño no difieren de los del resto de la casa. Los muros de cierre se realizan con tapial, sobre un primer tramo de zócalo, realizado con aparejo irregular a base de pequeños sillares de arenisca y, en algunos casos, utilizando también nódulos de caliza y cantos rodados. Algunas de las paredes conservaban revestimiento, como es el caso del muro septentrional y occidental del baño, además del muro interior que permite el acceso a la letrina ${ }^{43}$. El baño se pavimenta con distintos tipos de solera: la sala central, la letrina, la sala aneja este y el pasillo de acceso a la sala caliente, se pavimentan con losas de calcarenita, que permite su fácil limpieza; la sala caliente utiliza baldosas de barro cocido, que se caracterizan por ser buenas conductoras del calor; la sala aneja oeste cuenta con un suelo de tierra batida, un material poco aconsejable para una zona húmeda. El arrasamiento que sufre la sala del horno no permite identificar de manera clara su pavimento. Las estancias se cubrirían con una techumbre de tejas, tal y como muestran los materiales recuperados en las colmataciones de todos los espacios de la instalación. En ningún caso hay constancia de la utilización de cubrición con bóvedas y tragaluces, habituales en los baños públicos (PAVÓN, 1990: 345-348).

La situación independiente del baño con respecto al resto de la vivienda, le proporciona el aislamiento que estos recintos necesitan. Se encuentra a una cota inferior al del resto de espacios de la casa, que posibilita su protección del frío y alivia el gasto energético. Mientras que se realizase el baño, la puerta de por la que se accedía desde el patio permanecería cerrada, para evitar las fugas de calor y humedad. La mayor cuestión que nos encontramos al realizar el estudio e interpretación, tanto de la casa como del baño, es la ausencia de infraestructuras hidráulicas que abastezcan a la residencia. Esta información se obtendrá, sin duda, cuando se realicen los trabajos de seguimiento arqueológico pendientes en el solar. Las casas documentadas en el solar cuentan con pozos de agua en el patio, por lo que cabe pensar que la única vivienda con baño debería poseer,

\footnotetext{
43 Algunos autores consideran que el revestimiento parietal en el área húmeda del baño es poco aconsejable debido a su fragilidad, que lo incompatibiliza con las salas de baño con vapor (EPALZA, 1989: I5). En cambio, otros autores señalan que se trata de una práctica habitual de decoración (PAVÓN, 1990: 350-35I). Nos fue posible comprobar in situ, en Madinat al-Zahra', como tanto el baño de la Vivienda de la Alberca como el baño anejo al Salón de 'Abd al-Rahman III, presentaban en su área húmeda un revestimiento con placas de mármol hasta la mitad de la pared, y a partir de ahí, un enlucido con mortero de cal y pintura a la almagra, que alcanzaba hasta las bóvedas. Quisiéramos agradecer al entonces director del Conjunto Arqueológico de Madinat al-Zahra', D. Antonio Vallejo, la posibilidad que nos dio de visitar ambos baños, que en la actualidad se encuentran cerrados al público a la espera de su rehabilitación y puesta en valor.
} 
necesariamente, una fuente de abastecimiento que satisfaga el volumen de agua requerido para el funcionamiento de toda la instalación.

\subsection{Valoración del baño}

Hemos visto como se dota al baño de todos los elementos necesarios, pero adaptados a las dimensiones con las que cuenta el recinto, muy reducidas con respecto a los baños privados de los palacios o de las grandes propiedades. En relación a la extensión de la casa, se destina algo más del $20 \%$ de la superficie al baño ${ }^{44}$. Las dimensiones que presenta dentro de la totalidad de la vivienda, podría plantear el supuesto de que el baño diera servicio también a alguna de las residencias colindantes. Descartamos esta hipótesis, ya que no hemos hallado ningún otro acceso al baño, y esto supondría que el recorrido que debería realizar otro propietario para alcanzar el baño, invadiría el espacio más íntimo de la casa, que en el mundo islámico se encuentra celosamente protegido ${ }^{45}$. Para ponderar en su justa medida este baño, es necesario realizar la comparativa con otros de características similares, hallados en casas de arrabal. Los casos documentados son casi nulos, más aún si lo limitamos al periodo del califato cordobés. En este sentido, en las excavaciones realizadas en el sector nororiental del yacimiento de Cercadilla (FUERTES, 2007) se exhumó una vivienda con un baño privado ${ }^{46}$ cuyo marco cronológico y espacial permite evaluar el ejemplo que excavamos. El baño de Cercadilla se estructura en dos salas, una que contiene el baño propiamente dicho, con una superficie que no alcanza los $9 \mathrm{~m}^{2}$ y otra estancia asociada de unos $3 \mathrm{~m}^{2}$. Esto hace un total de aproximadamente $12 \mathrm{~m}^{2}$, un cifra muy alejada de los 50,70 $\mathrm{m}^{2}$ de superficie con la que cuenta nuestro ejemplo ${ }^{47}$. Esta diferencia se fundamenta en la complejidad que presenta el baño y en el área destinada al mismo. El baño de la Casa 25 de Cercadilla se sitúa en dos estancias, resultado de la compartimentación de la crujía occidental de la vivienda. El escaso espacio destinado al baño dentro de la casa de Cercadilla, reduce los elementos a un hipocausto, una bañera y una habitación que haría las veces de vestidor ${ }^{48}$. En nuestro caso, como ya hemos visto, el baño se aísla del resto de la vivienda en un recinto independiente, y el número de estancias aumenta para dar cabida a todos los pasos necesarios para la limpieza ritual. Además del baño de Cercadilla, se ha publicado otro ejemplo de baño privado asociado a una vivienda. Se trata del baño privado ubicado en la calle Polo de Medina de la ciudad de Murcia (POZO, 1991). En este caso, la casa se halla insertada en el caserío de la medina y su cronología avanza hasta el s.XIII ${ }^{49}$. A la hora de establecer la comparativa, nos encontramos con el problema de que no se ha documentado la totalidad de la planta, ya que solo se excavó el área de la sala caliente ${ }^{50}$. Su superficie se cifra aproximadamente en 7,25 $\mathrm{m}^{2}$, superando

44 Todas las dimensiones de la casa a la que hacemos referencia, se ajustan a la reconstrucción hipotética de la planta que hemos propuesto.

45 La vivienda urbana se considera el receptáculo de la mujer y del honor familiar ('ird), y debe cerrarse para evitar cualquier tipo de contacto indiscreto con el exterior (PÉREZ, 2009). En Madinat al-Zahra', hay un caso de baño compartido, entre la Vivienda de la Alberca y la Casa de Ya'far. Los accesos desde cada casa al baño son independientes, pero se encuentran en un ámbito palaciego, con áreas semi-públicas que no son extrapolables a las viviendas de arrabal.

46 La vivienda se identifica en el contexto general del arrabal califal de Cercadilla como Casa 25 (FUERTES, 2007: 58-59)

47 Todas las mediciones de la superficie de la Casa 25 del yacimiento de Cercadilla se han realizado sobre la planimetría aportada en FUERTES, 2007. Los resultados de las mediciones son aproximados, sin embargo, el escaso error de margen permite realizar la comparativa.

$48 \mathrm{El}$ espacio destinado al baño estaba pavimentado con losas de barro dispuestas sobre un hipocausto y sustentadas por pilas de ladrillos. A través de un pasillo en el ángulo noroeste se accedía al horno. En la esquina noreste se encontraba la bañera rectangular ( I,35 m. $\times$ 0,80 m.). Además de realizarse el baño en esta sala, debió de utilizarse como vestuario. El espacio ubicado al sur del baño pudo asumir la función de vestuario o de antesala al baño, ya que comunicaba tanto con éste como con el pasillo distribuidor de la vivienda (FUERTES, 2007: 58-59)

49 El baño amortiza en el s.XIII un cementerio islámico, que a su vez se fundó sobre una gran propiedad del s.X-XI (POZO, I99।: 79).

50 En relación con la sala caliente, al norte del hipocausto se adosa una estructura rectangular que se identifica con una pileta. En este lateral se hallaron también lo que podía ser los restos del horno, formado por un derrumbe de ladrillos quemados con abundante ceniza (POZO, 1991: 82). 
en varios metros las dimensiones de la sala caliente que hallamos en nuestro baño (3,90 $\mathrm{m}^{2}$ ), si bien, esta superficie engloba tanto la zona del hipocausto como la de una sala adyacente al sur. Si nos centramos exclusivamente en la superficie ocupada por el hipocausto, sobre el que se dispone un pavimento de ladrillos, vemos cómo se reduce a 2,70 $\mathrm{m}^{2}$, por lo que es inferior al hipocausto de nuestro baño.

Tras esta comparativa, se pone de manifiesto la envergadura del baño que presentamos, tanto por sus dimensiones como por la complejidad de su planta, siempre dentro de un contexto de pequeños baños asociados a viviendas modestas que alcanzan una evidente relevancia.

\section{CONSIDERACIONES FINALES}

No cabe duda de la importancia que adquiere el baño en la sociedad islámica, no solo con un carácter social, higiénico y terapéutico, que ya tenía en la etapa clásica, sino que ahora alcanza un carácter ritual asociado a obtener el estado de purificación legal o tahara (EPALZA, 1989: 20), necesario para poder realizar las oraciones diarias obligatorias y cumplir con los preceptos de la religión musulmana. Era posible hacer las abluciones menores en la propia vivienda, tal y como prueban tanto la arqueología, como las fuentes árabes (NAVARRO; JIMÉNEZ, 20 I 0: 162). En casas de Siyasa o Mértola, hay datos que indica la presencia de pequeños espacios en las que se realizaban, ubicados en el patio o en el pórtico (NAVARRO; JIMÉNEZ, 20 I0: 163-164). También las letrinas se podían utilizar para estos menesteres, especialmente relacionado con su uso por parte de las mujeres, ya que es un lugar íntimo que impide la exposición del cuerpo a la vista de otras personas (VIDAL, 2000: 108). La ablución mayor se realizaba generalmente en los baños públicos, no obstante, había palacios y casas ricas que tenían unos baños privados en las que se podían realizar con mayor comodidad (NAVARRO; JIMÉNEZ, 20 I 0: 162). El hallazgo de pequeños baños en viviendas de arrabal indica que algunos habitantes con cierto poder adquisitivo se hacían construir estas instalaciones en su propiedad, a imitación de personajes importantes de la sociedad. Los pocos casos hallados evidencian la poca proliferación que tuvieron; sin embargo, habría que considerar algunos factores que influyen en su detección, que tienen que ver con el proceso de intervención y documentación. En muchas ocasiones, los propios límites de la excavación no permiten exhumar completamente la planta de las casa $y$, dado el reducido desarrollo que tienen algunos de los casos hallados, tal vez no se detecten los elementos que permitan su identificación, como puede ser el sistema de calefacción o alguna pila. Además, los materiales utilizados en estos pequeños baños no difieren en gran medida de los empleados en el resto de la vivienda, y su estado de conservación es similar. No ocurre así con el hammam público, que cuenta con muros muy sólidos e impermeables en la zona húmeda y calurosa del edificio, que soportaba cubiertas con pesadas bóvedas de piedra, lo que ha permitido, en muchos casos, que estas salas hayan permanecido en un aceptable estado de conservación (NAVARRO; JIMÉNEZ, 2009: I05). Sea como fuere, el ejemplo que hemos presentado permite vislumbrar las características que tendrían estos baños modestos, teniendo en cuenta, además, que se encuentra en un recinto independiente destinado a tal uso. Tanto este caso como los otros citados se antojan insuficientes para poder establecer una tipología de pequeños baños privados, por lo que las futuras excavaciones y las publicaciones aún pendientes permitirán un estudio más amplio de estos escasos elementos dentro del urbanismo andalusí.

\section{BIBLIOGRAFÍA}

ACIÉN ALMANSA: Manuel; VALLEJO TRIANO, Antonio (1998):"Urbanismo y Estado islámico: de Corduba a Qurtuba - Madinat al-Zahrā"'. Genèse de la ville islamique en alAndalus et au Maghreb occidental. Madrid, pp. I07-I36.

ALBA CALZADO, Miguel A.; FEIJOO MARTíNEZ, Santiago (2009): "Mérida islámica (s.VIII-IX): El proceso de transformación de la ciudad tardoantigua en una medina". Xelb, N9. Silves, pp. 191-228.

ALCALÁ LIRIO, Francisca; ARIAS DE HARO, Francisco; SUÁREZ MARQUEZ, Ángela (2005): "Nuevas perspectivas de investigación arqueológicas". La Alcazaba. Fragmentos para una historia de Almería. Almería, pp. I5 - 162. 
ALMAGRO GORBEA, Antonio (1999):"El baño del alcázar omeya de Amman". De oriente a occidente. Homenaje al Dr. Emilio Olávarri. Salamanca, pp. 8|-| I2.

ALMAGRO GORBEA, Antonio; ALMAGRO GORBEA, Martín; CABALLERO, Luís; ZOZAYA STABEL-HANSEN, Juan (1975): "Qusayr 'Amra. Residencia y baños omeyas en el desierto de Jordania". Madrid.

APARICIO SÁNCHEZ, Laura (2002): "Informe-memoria de la Actividad Arqueológica Preventiva P.E.R.I. 9-A, P.G.O.U. de Córdoba". Informe Administrativo depositado en la Delegación Provincial de Cultura de Córdoba. Inédito.

AZUAR RUÍZ, Rafael (1989): “El hammam musulmán en al-Andalus". Baños árabes en el País Valenciano. Valencia, pp. 33-43.

BAÑOS SERRANO, José (1996): "Los baños termales minero-medicinales de Alhama de Murcia". Memorias de arqueología. № 5, 1990. Murcia, pp. 354-381.

BERGES ROLDÁN, Luis (1976): "Los baños árabes de la alta Andalucía". Actas XXIII Congreso internacional de Historia del Arte, II. Universidad de Granada, 1973, pp. 49-54.

BERGES ROLDÁN, Luis (1989): "Baños árabes del Palacio de Villardompardo, Jaén". Jaén.

BERMÚDEZ CANO, José M. (1993): "La trama viaria propia de Madinat al-Zahra y su integración con la de Córdoba". Anales de arqueología cordobesa. № 4. Córdoba, pp. 259-294.

BERMÚDEZ CANO, José M. et alii (2004): "Informe de resultados preliminares de la I.A.U. del edificio de usos múltiples del área de infraestructuras del Ayuntamiento de Córdoba, El Fontanar, Parque Cruz Conde". Informe administrativo depositado en la Delegación de Cultura de Córdoba (inédito).

BERTRAND, Maryelle; SÁNCHEZ VICIANA, José R. (2006): "Intervenciones arqueológicas en apoyo de la restauración de los baños árabes de la judería de Baza. Campaña 2003". Anuario Arqueológico de Andalucía 2003. Vol. II. Sevilla, pp. 163-180.

CABRERA MUÑOZ, Emilio (1999): "Aproximación a la imagen de la Córdoba islámica", Córdoba en la Historia: la construcción de la Urbe. Actas del Congreso (20-23 de mayo, 1997). Córdoba, pp. I I I- 128.

CAMACHO CRUZ, Cristina (2002): "Nuevos vestigios arqueológicos de la Córdoba Omeya. Actuaciones arqueológicas en el trazado de la Ronda de poniente". Arte, arqueología e historia. № 9. Córdoba, pp. I 18-132.

CAMACHO CRUZ, Cristina; HARO TORRES, Miguel; LARA FUILLERAT, José M.; Pérez navarro, César (2004): "Intervención Arqueológica de Urgencia en el arrabal hispanomusulmán "Casas del Naranjal". Yacimiento "D". Ronda oeste de Córdoba". Anuario Arqueológico de Andalucía 200 I. Vol. III. Sevilla, pp. 21-230.

CARA BARRIONUEVO, Lorenzo; RODRÍGUEZ LÓPEZ, Juana Ma (1982): "Los Baños de la Reina de Celin (Dalias, Almería)". Boletín del Instituto de Estudios Almerienses. $N^{\circ}$ 2. Almeria, pp. 109-1 I3.
CASAL GARCÍA, Ma Teresa (2008):"Características generales del urbanismo cordobés de la primera etapa emiral: El Arrabal de Saqunda". Anejos de Anales de Arqueología Cordobesa. № I. Córdoba, pp. 109-134.

CASAL GARCÍA, MảTeresa (20 I0): "Actividad Arqueológica Preventiva para la ampliación del Hospital Universitario Reina Sofía y la construcción del Centro de Investigación Biomédica de la UCO". Informe Administrativo depositado en la Delegación Provincial de Cultura de Córdoba. Inédito.

CASAL GARCÍA, Ma Teresa; LEÓN MUÑOZ, Alberto; LÓPEZ GUERRERO, Rosa; VALDIVIESO RAMOS, Ana; SORIANO CASTRO, Patricio J. (2006): "Espacios y usos funerarios en la Qurtuba islámica". Anales de arqueología cordobesa. N 17, vol.Il. Córdoba, pp. 257-290.

CASTAÑO BLÁZQUEZ, Trinidad; JIMÉNEZ CASTILLO, Pedro (2004): "Los baños árabes de San Lorenzo (Murcia)". Memorias de arqueología. № 12, 1997. Murcia, pp. 533-544.

CASTRO DEL RÍO, Elena (2005):"El arrabal de época califal en la Zona Arqueológica de cercadilla: La arquitectura doméstica". Arqueología cordobesa. No 12. Córdoba.

DORTEZ CÁCERES, Teresa (20 I0): "Urbanismo islámico en el sector central del Yanib al-Garbi". El Anfiteatro romano de Córdoba y su entorno urbano. Monografias de Arqueología Cordobesa. No 19, vol.ll. Córdoba, pp. 621-628.

EIROA RODRIGUEZ, Jorge A. (1999-2000): “Los baños de Fortuna: Un ejemplo de termalismo medieval en la región de Murcia". Miscelánea medieval murciana. Vol. XXIII-XXIV. Murcia, pp. 8-29.

EPALZA FERRER, Mikel de (1989):"Estructuras y funciones de los baños islámicos". Baños árabes en el País Valenciano. Valencia, pp. I|-24.

EWERT, Christian (|99|): "Precursores de Madinat alZahrā'. Los palacios omeyas y abbāsies de oriente y su ceremonial áulico". Cuadernos de Madinat al-Zahra. Vol.3. Córdoba, pp. 123-163.

FEIJOO MARTÍNEZ, Santiago (2000): "Intervención arqueológica en la zanja para la canalización de aguas de la C/ Nerja. Unas termas de época visigoda extramuros de la ciudad". Mérida, Excavaciones Arqueológicas Nº4, 1998. Mérida, pp. 29|-30|.

FERNÁNDEZ OCHOA, Carmen; GARCÍA-ENTERO, Virginia; MORILLO CERDÁN, Ángel; ZARZALEJOS PRIETO, Mar (2004): "Proyecto Termas Romanas en Hispania. Balance de una década de investigación (1993-2003)". Cuadernos de Prehistoria y Arqueología. No 30. Madrid, pp. 167-186.

FOURNIER, Caroline (2008): "Les bains publics d'alAndalus, espaces de "convivialité"? (IX-XV siècles)". La convivencia en las ciudades medievales. Logroño, pp. 3| |-32|.

FUERTES SANTOS, Ma Camino (2007): "El sector nororiental del arrabal califal del yacimiento de Cercadilla. Análisis urbanístico y arquitectónico". Arqueología y territorio medieval. $\mathrm{N}^{\circ}$ | 4. Jaén, pp. 49-68. 
FUERTES SANTOS, Ma Camino; RODERO PÉREZ, Santiago; ARIZA RODRÍGUEZ, Javier (2007): "Nuevos datos urbanísticos en el área de la puerta del palatinum de Córdoba". Romula. № 6. Sevilla, pp. 173-210.

GARCÍA-ENTERO, Virginia (2005-2006): "Las transformaciones de los balnea rurales domésticos durante la Antigüedad tardía en Hispania (ss. IV-VI)". Cuadernos de prehistoria y arqueología. No 31-32. Madrid, pp. 6I-82.

GARCÍA-ENTERO, Virginia (2006): "Los balnea domésticos - ámbito rural y urbano - en la Hispania romana". CSIC. Madrid.

GARCÍA-ENTERO, Virginia; ARRIBAS DOMÍNGUEZ, Raúl (2000): "Los balnea de las villae y su proceso de monumentalización". Termas romanas en el occidente del imperio. Gijón, pp. 83-96.

GARCÍA LÓPEZ, José L. (1990): “Excavación arqueológica efectuada en los baños hispano-musulmanes del Hizan (Celin-Dalias). Almería, 1987". Anuario Arqueológico de Andalucía 1987. Vol. III. Madrid, pp. 37-40.

GILOTTE, Sophie; SUÁREZ MÁRQUEZ, Ángela; ALCALÁ LIRIO, Francisca; ARIAS DE HARO, Francisco (20 I 0): "Los baños de la tropa de la Alcazaba de Almería: Resultados preliminares de la Intervención Arqueológica". Cuadernos de Madinat al-Zahra. Vol.7. Córdoba, pp. 219-238.

HERNÁNDEZ PARDO, Antonio; FRANCO CALVO, Jesús G. (2006): "Un baños islámico en el castillo de Albarracín". Baños árabes de Toledo. Monográficos del Consorcio, $N^{\circ} 2$. Toledo, pp. 183-196.

HIDALGO PRIETO, Rafael (2007): "La puerta del Palatinum de Corduba". Romula. No 6. Sevilla, pp. I43- 172.

JIMÉNEZ CASTILLO, Pedro; NAVARRO PALAZÓN, Julio (2002): "Casas califales en Murcia. Excavación en un solar de calles Puxmarina-Zarandona". Memorias de arqueología. No I I, 1996. Murcia, pp. 469-500.

KENNEDY, H (1985):" "From polis to medina: Urban change in late Antiquity and Early Islamic Syria". Past and present. $\mathrm{N}^{\circ}$ 106, pp. 3-27.

LARA GARCÍA, Ma Pepa (1995): "Los baños árabes en Málaga". Isla de Arriarán: revista cultural y científica. № 5. Málaga, pp. 103-120.

LEÓN MUÑOZ, Alberto (2006): "Pervivencias de elementos clásicos en la Qurtuba islámica". El concepto de lo provincial en el mundo antiguo. Vol. II. Córdoba, pp. 409-438.

LEÓN MUÑOZ, Alberto; BLANCO, Rafael (20l0): "La fitna y sus consecuencias. La revitalización urbana de Córdoba en época almohade". El Anfiteatro romano de Córdoba y su entorno urbano. Monografías de Arqueología Cordobesa. №19, vol.ll. Córdoba, pp. 699-726.

LEÓN MUÑOZ, Alberto; CASAL GARCÍA, Ma Teresa (20।0): "Los cementerios de Madinat Qurtuba". El Anfiteatro romano de Córdoba y su entorno urbano. Monografias de Arqueología Cordobesa. N 19, vol.II. Córdoba, pp. $651-684$.
LLAMAS SEGARRA, Horacio et alii (2009): "Intervención Arqueológica Preventiva en el solar $n^{\circ} 10$ de la calle Sebastián Soubiron de Málaga". Anuario Arqueológico de Andalucía 2004. Vol. I, pp. 2553-2568.

LLOBREGAT CONESA, Enrique A. (1989): "Las termas romanas como precedente del hammam islámico". Baños árabes en el País Valenciano. Valencia, pp. 25-31.

LÓPEZ ELUM, Pedro (1994): "La alquería islámica en Valencia: estudio arqueológico de Bofilla, siglos XI a XIV". Valencia.

LÓPEZ GUERRERO, Rosa; VALDIVIESO RAMOS, Ana (200 I): "Las mezquitas de barrio en Córdoba: estado de la cuestión y nuevas líneas de investigación". Anales de arqueología cordobesa. № 12. Córdoba, pp. 215-239.

-LÓPEZ OSORIO, José M.; TORRES CARBONELL, José M. (2008): "El análisis estratigráfico del baño árabe de Churriana de la Vega (Granada): Síntesis del conocimiento como base del proyecto de restauración". Arqueología de la arquitectura. $N^{\circ}$ 5. Universidad del País vasco, pp. 187-206.

LUNA OSUNA, Dolores; CARMONA ÁVILA, Rafael (20I I): "El hammām andalusí de la Puerta de Santa Ana (madinat Bāgut, Priego de Córdoba)". Antiquitas. № 23. Priego de Córdoba, pp. 197-232.

MANZANO MARTOS, Rafael (1958): "El baño termal de Alhama de Granada". Al-Andalus. N XXIII, vol. II. pp. 408-4I6.

MARFIL RUÍZ, Pedro (1999): "Avance de resultados del estudio arqueológico de la fachada del oratorio de Abd al-Rahmán I en la mezquita de Córdoba". Cuadernos de Madinat al-Zahra. Vol.4. Córdoba, pp. 175-207.

MARFIL RUÍZ, Pedro (200I): "Córdoba de Teodosio a Abd al-Rahmán III". Visigodos y Omeyas. Un debate entre la Antigüedad Tardía y la Alta Edad Media (I Simposio Internacional de Mérida. 1999). Anejos de Archivo Español de Arqueología. No XXIII, pp. I |7-|4|

MARFIL RUÍZ, Pedro (2004): "Los baños del Alcázar Califal de Córdoba. Resultados de la Intervención Arqueológica desarrollada en el año 2000". El agua a través de la historia. Estudios de Historia. Nol, pp. 49-76.

MARFIL RUÍZ, Pedro (2008):"Informe preliminar y memoria científica de la intervención arqueológica puntual en el Baño de San Pedro, Calle Carlos Rubio 8, 10 y 12 (Córdoba)". Informe Administrativo depositado en la Delegación Provincial de Cultura de Córdoba. Inédito.

MARFIL RUÍZ, Pedro; PENCO VALENZUELA, Fernando (1997): "Resultados suscintos de la Intervención Arqueológica de Urgencia en el Hamman del Alcázar califal, Campo Santo de los Mártires S/N (Córdoba). 9 de Noviembre de 1993 a 10 de Febrero de 1994". Anuario Arqueológico de Andalucía 1993. Vol. III. Sevilla, pp. 91 - I0I.

MARTIN-BUENO, Manuel; REKLAITYTE, leva; SÁENZ PRECIADO, José C.; URIBE AGUDO, Paula (2007): "Baños y letrina en el mundo romano: el caso del Balneum de la Domus I del barrio de las termas de Bilbilis". Zephyrus. No 60. Salamanca, pp. 221-239. 
MARTÍNEZ JIMÉNEZ, Javier (20I I): "The continuity of roman water supply systems in post-roman Spain: the case of Valentia, a reliable example?". Arkeogazte. $N^{\circ}$ I. Vitoria-Gasteiz, pp. 125-144.

MATEOS CRUZ, Pedro; AlBA CALZADO, Miguel A. (200 I): "De Emerita Augusta a Marida". Visigodos y Omeyas. Un debate entre la Antigüedad Tardía y la Alta Edad Media (I Simposio Internacional de Mérida. 1999). Anejos de Archivo Español de Arqueología. N XXIII, pp. I43-I 68.

MAYORGA MAYORGA, José; RAMBLA TORRALVO, J. Antonio (2009): "Urbanismo romano bajoimperial y baño musulmán en las excavaciones del Pasillo de guimbarda. Málaga". Anuario Arqueológico de Andalucía 2004. Vol. I. Sevilla, pp. 2794-28I3.

MELCHOR GIL, Enrique (1995): "Vías romanas de la provincia de Córdoba". Córdoba.

MILETO, Camila;VEGAS LÓPEZ-MANZANARES, Fernando (2003): "El análisis estratigráfico constructivo aplicado en casos específicos: los Baños Árabes de Hernando de Zafra (Granada) y la Galería Superior del Patio de los Arrayanes de la Alhambra de Granada". Arqueología de la arquitectura, $N^{\circ}$ 2. Universidad del País vasco, pp. $213-218$.

MONTEJO CÓRDOBA, Alberto J. ( 1999): "El pabellón de abluciones oriental de la Mezquita aljama de Córdoba correspondiente a la ampliación de Almanzor". Cuadernos de Madinat al-Zahra. Vol.4. Córdoba, pp. 209-231.

MONTEJO CÓRDOBA, Alberto J. (2003): "Los baños". Guía arqueológica de Córdoba. Córdoba, pp. 177-I80.

MUÑOZ LÓPEZ, Francisco (2006): "Informe de la excavación arqueológica en calle San Antonio, 19 (Murcia)". Memorias de arqueología. № 14, 1999. Murcia, pp. 475-490.

MUÑOZVÁZQUEZ, Miguel (1961-62):"Los baños árabes de Córdoba". Al-Mulk. N 2. Córdoba, pp. 53-117.

MURILLO REDONDO, Juan F. (2009): "La almunia de al-Rusafa en Córdoba". Madrider Mitteilungen. № 50 Mainz, pp. 450-482.

MURILLO REDONDO, Juan. F;; FUERTES SANTOS, $M^{a}$ Camino:; LUNA OSUNA, Dolores (1999):"Aproximación al análisis de los espacios domésticos en la Córdoba andalusî'. Córdoba en la Historia: la construcción de la urbe. Actas del Congreso. Córdoba, pp. 129-154.

MURILLO REDONDO, Juan F; CASAL GARCÍA, MaTeresa; CASTRO DEL RÍO, Elena (2004): "Madinat Qurtuba. Aproximación al proceso de formación de la ciudad emiral y califal a partir de la información arqueológica". Cuadernos de Madinat al-Zahra. Vol.5. Córdoba, pp. 257-290.

MURILLO REDONDO, Juan F.; CASTILLO PÉREZ DE SILES, Fátima; CASTRO DEL RÍO, Elena; CASAL GARCÍA, Ma Teresa; DORTEZ CÁCERES, Teresa (20l0a): "La almunia y el arrabal de al-Rusafa, en el Yanib al-Garbi de Madinat Qurtuba". El Anfiteatro romano de Córdoba y su entorno urbano. Monografías de Arqueología Cordobesa. N 19, vol.Il. Córdoba, pp.565-615.
MURILLO REDONDO, Juan F.; LEÓN MUÑOZ, Alberto; CASTRO DEL RÍO, Elena; CASAL GARCÍA, Ma Teresa; ORTIZ URBANO, Raimundo; González ruiz, Antonio José (20 I Ob): "La transición de la civitas clásica cristianizada a la madina islámica a través de las transformaciones operadas en las áreas suburbiales". El Anfiteatro romano de Córdoba y su entorno urbano. Monografías de Arqueología Cordobesa. N 19, vol.Il. Córdoba, pp. 503-547.

NAVARRO PALAZÓN, Julio; JIMÉNEZ CASTILLO, Pedro (1996): "Estudio sobre once casas andalusíes en Siyasa". Memorias de Arqueología. No 5, 1990. Murcia, pp. 526-595.

NAVARRO PALAZÓN, Julio; JIMÉNEZ CASTILLO, Pedro (2003): "Sobre la ciudad islámica y su evolución". Estudios de arqueología dedicados a la profesora Ana María Muñoz Amilibia. Murcia, pp. 319-38|.

NAVARRO PALAZÓN, Julio; JIMENEZ CASTILLO, Pedro (2009): "Arqueología del baño andalusî". Actas de los XIX cursos monográficos sobre el Patrimonio Histórico. Santanderl Reinosa, pp. 95- 137.

NAVARRO PALAZÓN, Julio; JIMENEZ CASTILLO, Pedro (20 I0): "El agua en la ciudad andalusî". Actas del II Coloquio Internacional Irrigación, Energía y Abastecimiento de Agua: La cultura del agua en el arco mediterráneo (Alcalá de Guadaira, 3-9 de noviembre de 2008). Alcalá de Guadaira, pp. 147-254.

NAVARRO PALAZÓN, Julio; JIMENEZ CASTILLO, Pedro (20I I): "Materiales y técnicas constructivas en la Murcia andalusí (siglos X-XIII)". Arqueología de la arquitectura. $\mathrm{N}^{\circ}$ 8, pp. 85- 120

NAVARRO PALAZÓN, Julio; ROBLES FERNÁNDEZ, Alfonso (1993):"El baño árabe de San Nicolás de Murcia. Memoria Preliminar". Memorias de arqueología. № 4, 1989. Murcia, pp. 329-339.

ONTALBA RUIPÉREZ, José A. (1995): "El baño, el lecho y el hábito en las reglas monásticas visigodas del siglo VII y en sus fuentes". Monjes y monasterios españoles (Actas del simposium). Vol. III, pp. 795-8I4.

PASSINI, Jean (2006): "Los baños y el agua en Toledo". Baños árabes de Toledo. Monográficos del Consorcio. № 2 . Toledo, pp. 31-46.

PASSINI, Jean (20 I 0): "El baño de bab al-Mardum (o de la Cruz): localización e identificación". Al-Qantara. N XXXI, Vol. I. Madrid, pp. 21 I-223.

PAVÓN MALDONADO, Basilio (1990): "Tratado de arquitectura hispanomusulmana I. Agua". Madrid.

PÉREZ ORDOÑEZ, Alejandro (2009): "Algunos apuntes sobre las mujeres en la casa andalusí". I Congreso virtual sobre Historia de las mujeres. Jaén.

POZO MARTÍNEZ, Indalecio (|99|): "Un baño privado islámico en la calle Polo de Medina (Murcia)". Verdolay. No 3. Murcia, pp. 79-94.

REKLAITYTE, leva (2004): "Las condiciones higiénicosanitarias en las ciudades europeas: introducción al análisis". Saldvie. № 4. Zaragoza, pp. 229-245. 
REKLAITYTE, leva (2005): "El saneamiento de las ciudades andalusíes". Anales de arqueología cordobesa. No 16. Córdoba, pp. 207-238.

REKLAITYTE, leva (2006): "Acerca del saneamiento de las mudum andalusíes". Saldvie. № 6. Zaragoza, pp. 225-249.

REKLAITYTE, leva (2007): "Importancia y aprovechamiento del agua en el mundo medieval islámico". Saldvie. $N^{\circ}$ 7. Zaragoza, pp. |59-17|.

REKLAITYTE, leva (2008): "La vecindad en peligro: el saneamiento de la madîna andalusî". La convivencia en las ciudades medievales. Logroño, pp. 333-349.

ROBLES FERNÁNDEZ, Alfonso; RAMIREZ ÁGUILA, Juan A.; NAVARRO SANTA-CRUZ, Elvira (1993):"Influencia de las mentalidades en el urbanismo andalusí: la interacción funcional de baños y cementerios en Murcia". Sociedades en transición. IV Congreso de Arqueología Medieval Española. Alicante, pp. 95-102

RODRÍGUEZ GUTIÉRREZ,Antonio J. (2009) "A.A.P. en Cl Ronda de los Mártires, n 7 de Córdoba". Anuario Arqueológico de Andalucía, 2004. I. Vol. III. Sevilla, pp. 792-799.

RUIZ LARA, Dolores; CASTRO DEL RÍO, Elena; LEÓN MUÑOZ,Alberto; SÁNCHEZ MADRID, Sebastián (20 I 0): "El sector meridional del Yanib al-Garbi". El Anfiteatro romano de Córdoba y su entorno urbano. Monografías de Arqueología Cordobesa. № 19, vol.Il. Córdoba, pp. 629-642.

RUIZ LARA, Dolores; MURILLO REDONDO, Juan F; CARRILLO DÍAZ-PINÉS, José R:; CARMONA BERENGUER, Silvia; GONZÁLEZ VÍRSEDA, Marina L;;VARGAS CANTOS, Sonia (2003): "Resultados de la intervención arqueológica realizada en el Palacio de Orive de Córdoba (1996-1998)". Anuario Arqueológico de Andalucía, 2000. Vol. III. Sevilla, pp. 299-321.

SALVATIERRA CUENCA,Vicente; CASTILLO ARMENTEROS, Juan C.; CASTILLO ARMENTEROS, José L. (1993): "El baño árabe del naranjo y la formación del edificio Los Caños". Jaén.

VALOR PIECHOTTA, Magdalena (1995): "Los baños en la Sevilla islámica”. Arqueología medieval. № 3, pp. 161-170.

VARELA GOMES, Rosa (2003): "Silves (Xelb), uma cidade do Gharb al-Andalus: a Alcáçova". Trabalhos de arqueología, n 35. Instituto Português de Arqueologia. Lisboa, pp. 85- 107.
VIDAL CASTRO, Francisco (2000): "Agua y urbanismo: evacuación de aguas en las fatwà-s de al-Andalus y el norte de África". Urbanisme musulman. Madrid, pp. 101-123.

VALLEJO TRIANO, Antonio (1987): "El bañó próximo al Salón de 'Abd al-Rahmān III'. Cuadernos de Madinat al-Zahrā'. Vol.I. Córdoba, pp. |4|-165.

VALLEJO TRIANO, Antonio (1990): "La vivienda de servicios y la llamada casa de Ya'far". La casa hispanomusulmana: aportaciones de la Arqueología. Granada, pp. |29-| 46.

VALLEJO TRIANO, Antonio (2004): "Guía oficial del Conjunto Arqueológico de Madinat al-Zahra". Consejería de Cultura de la Junta de Andalucía. Sevilla.

VALLEJO TRIANO, Antonio (2007): "Madinat al-Zahra. Notas sobre la planificación y transformación del palacio". Artigrama. N²2. Zaragoza, pp. 73-101.

VALLEJO TRIANO, Antonio (20I0): "La ciudad califal de Madinat al-Zahra: arqueología de su arquitectura". Córdoba.

VALLEJO TRIANO, Antonio; MONTEJO CÓRDOBA, Alberto; GARCÍA CORTÉS, Andrés (2004): "Resultados preliminares de la Intervención Arqueológica en la "Casa de Ya'far" y en el edificio de "Patio de los pilares de Madinat al-Zahra". Cuadernos de Madinat al-Zahra. Vol.5. Córdoba, pp. 199-239.

VÁZQUEZ NAVAJAS, Belén (20।0): "La gestión del agua en los arrabales occidentales de Madinat Qurtuba". El Anfiteatro romano de Córdoba y su entorno urbano. Monografias de Arqueología Cordobesa. N 19, vol.ll. Córdoba, pp. 643-65l.

VELÁZQUEZ SORIANO, Isabel; RIPOLL LÓPEZ, Gisela (1992):"Pervivencias del termalismo y el culto a las aguas en época visigoda hispánica". Espacio, tiempo y forma, Serie II, Historia Antigua, pp. 555-580.

VIDAL CASTRO, Francisco (2000): "Agua y urbanismo: Evacuación de aguas en fatwà-s de al-Andalus y el Norte de África". L'urbanisme dans l'occident musulmana au moyen âge: aspects juridiques. CSIC, pp. I0I-I 23.

VILCHEZ VILCHEZ, Carlos (200I): "Baños árabes". Granada. 


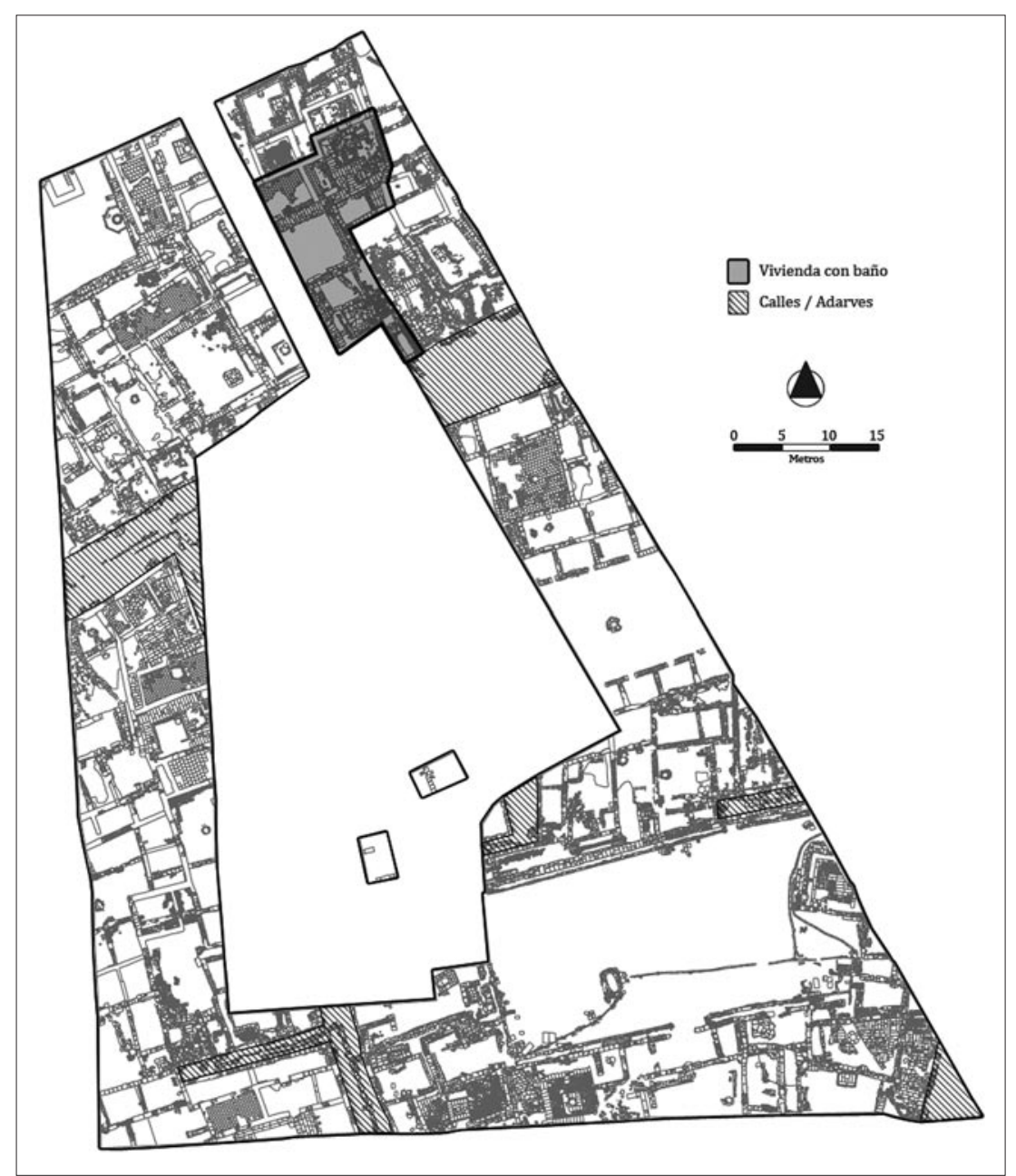

Fig. I. Planimetría del arrabal califal (ss.X-XI).

Fig. 2. Ubicación de la vivienda en el parcelario andalusí excavado.

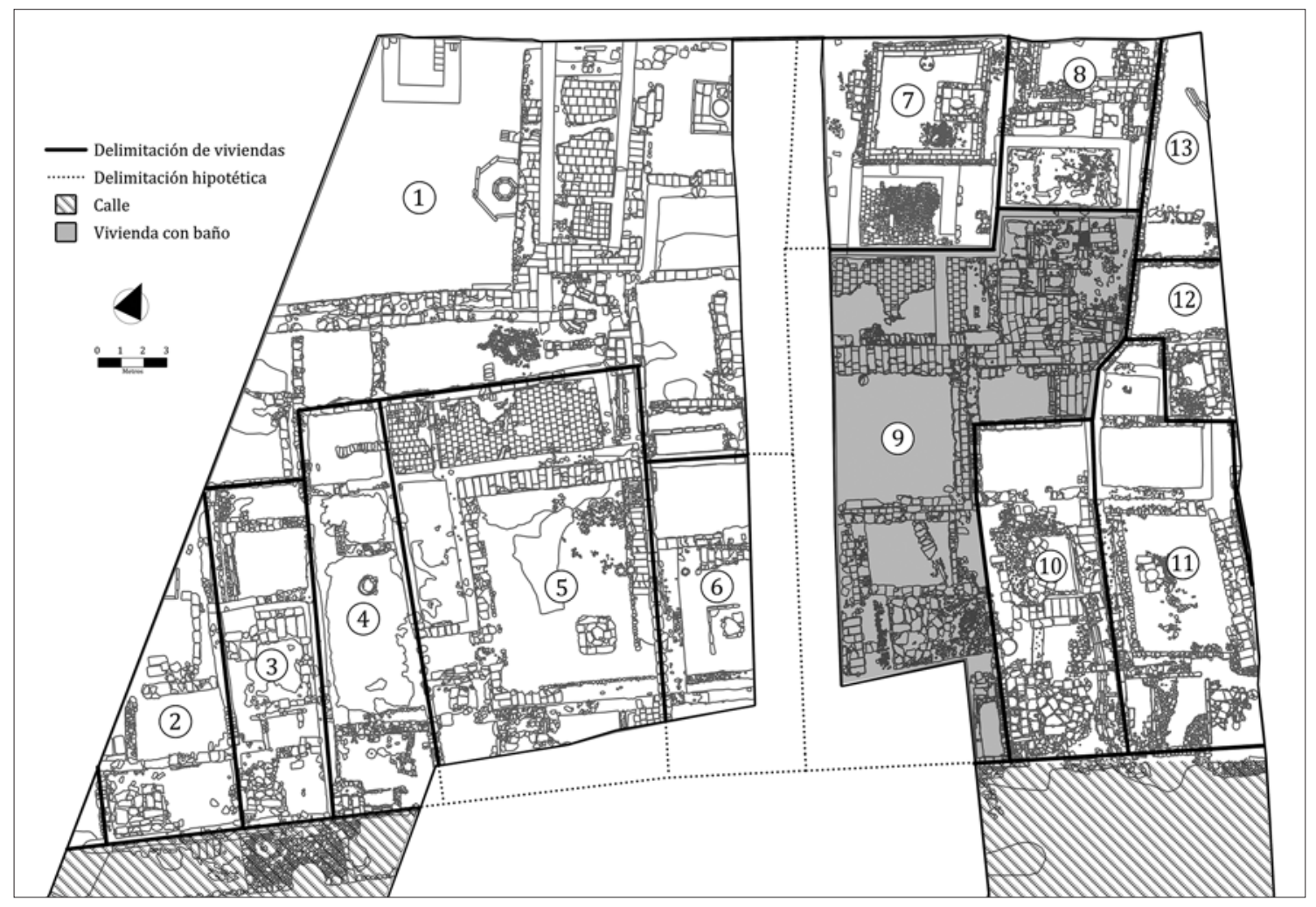




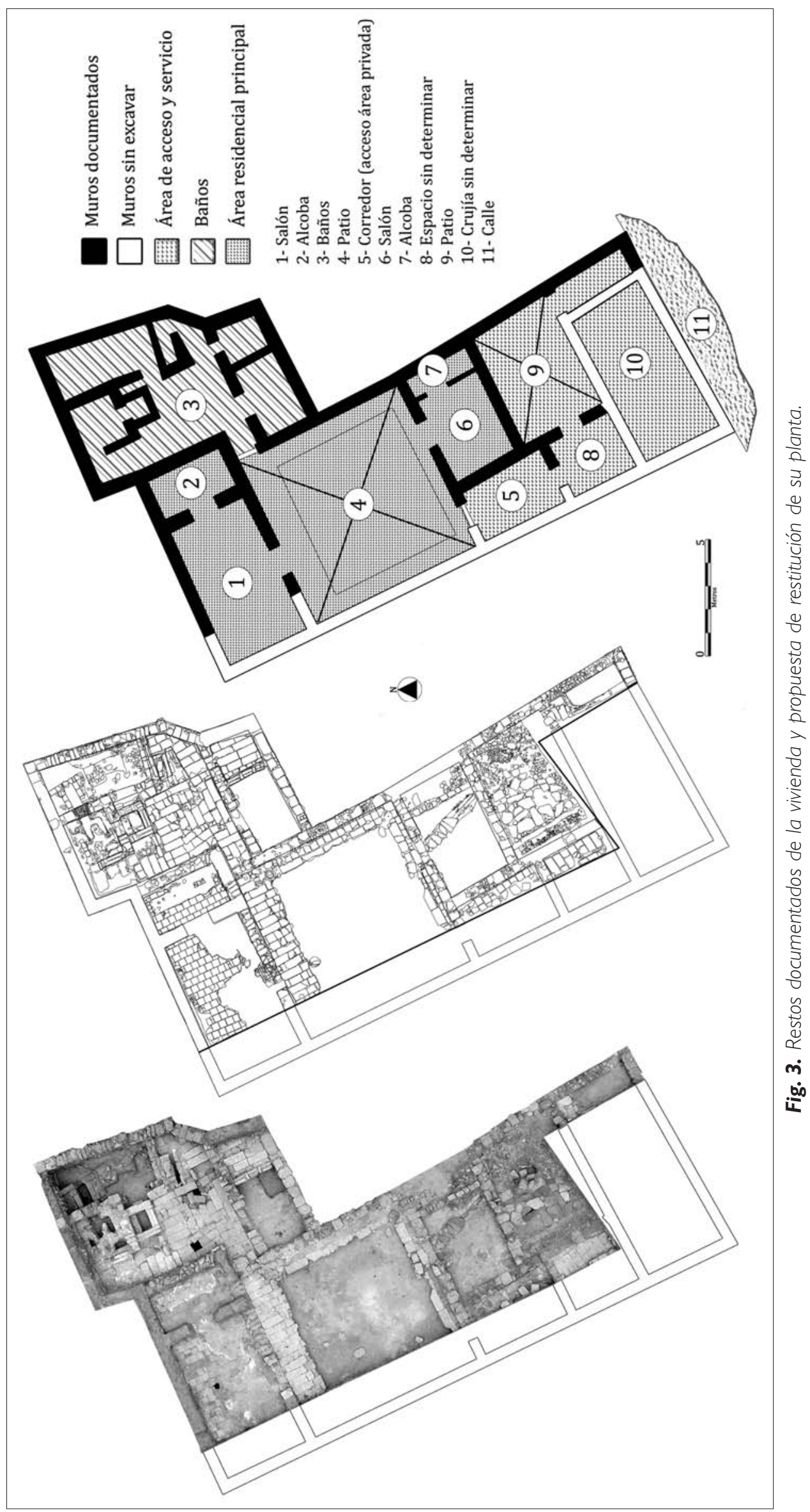




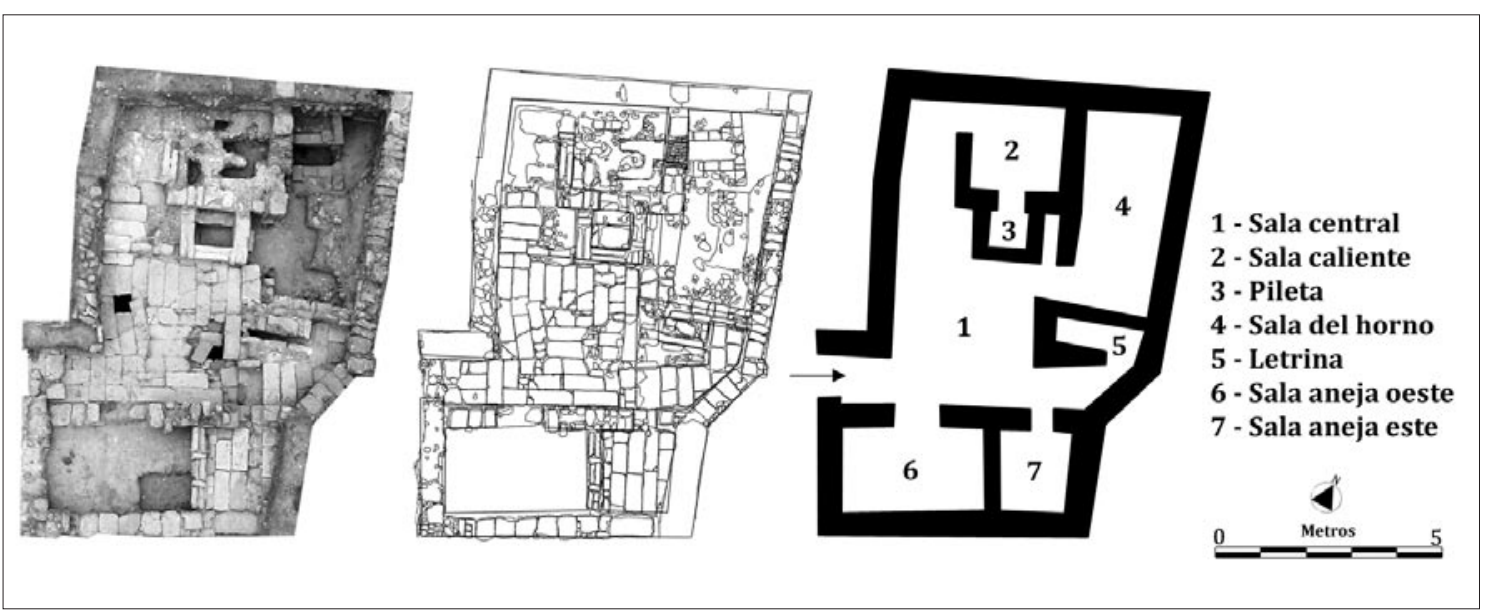

Fig. 4. Planta del baño.

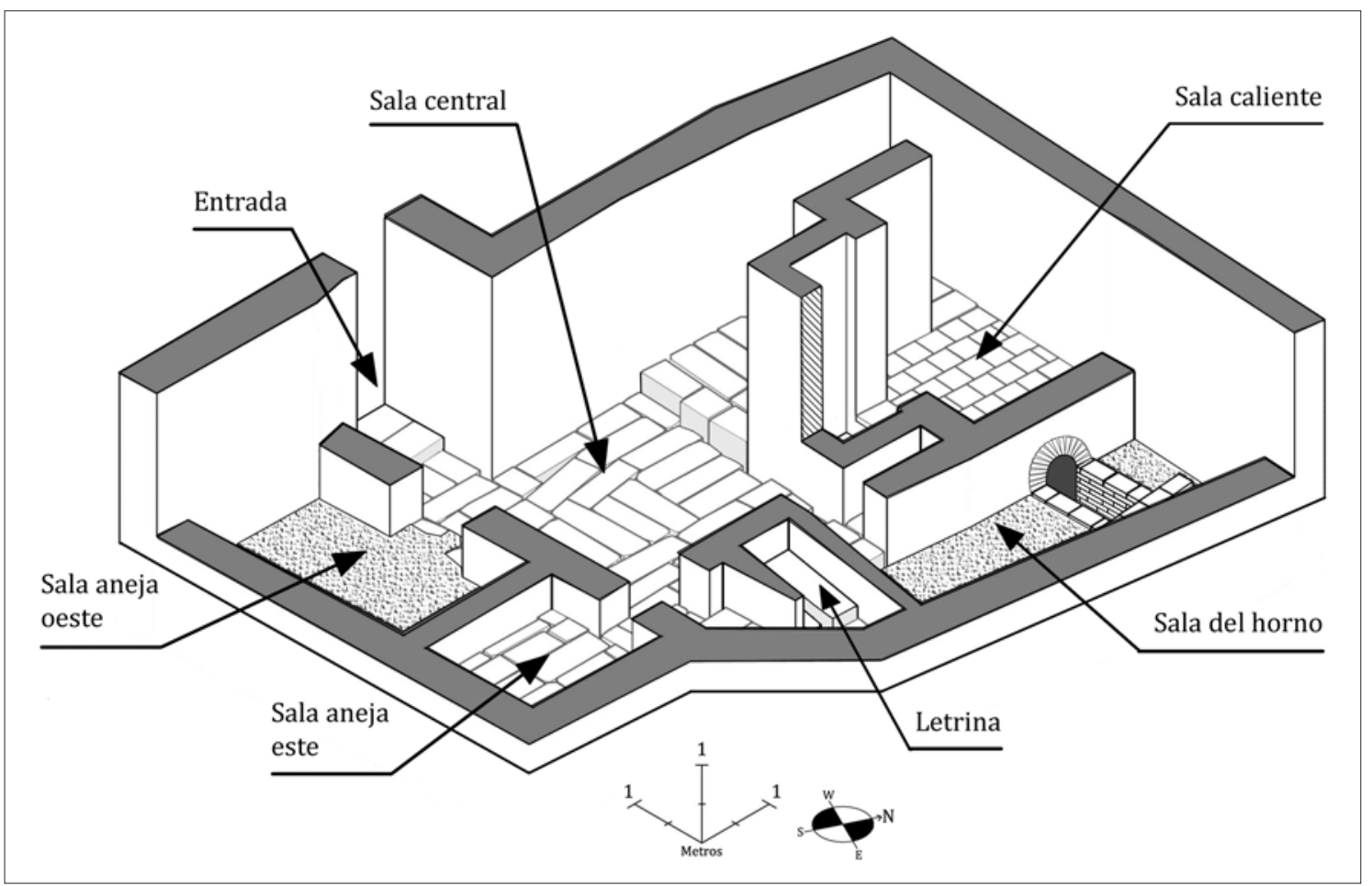

Fig. 5. Restitución volumétrica del baño (vista isométrica). 

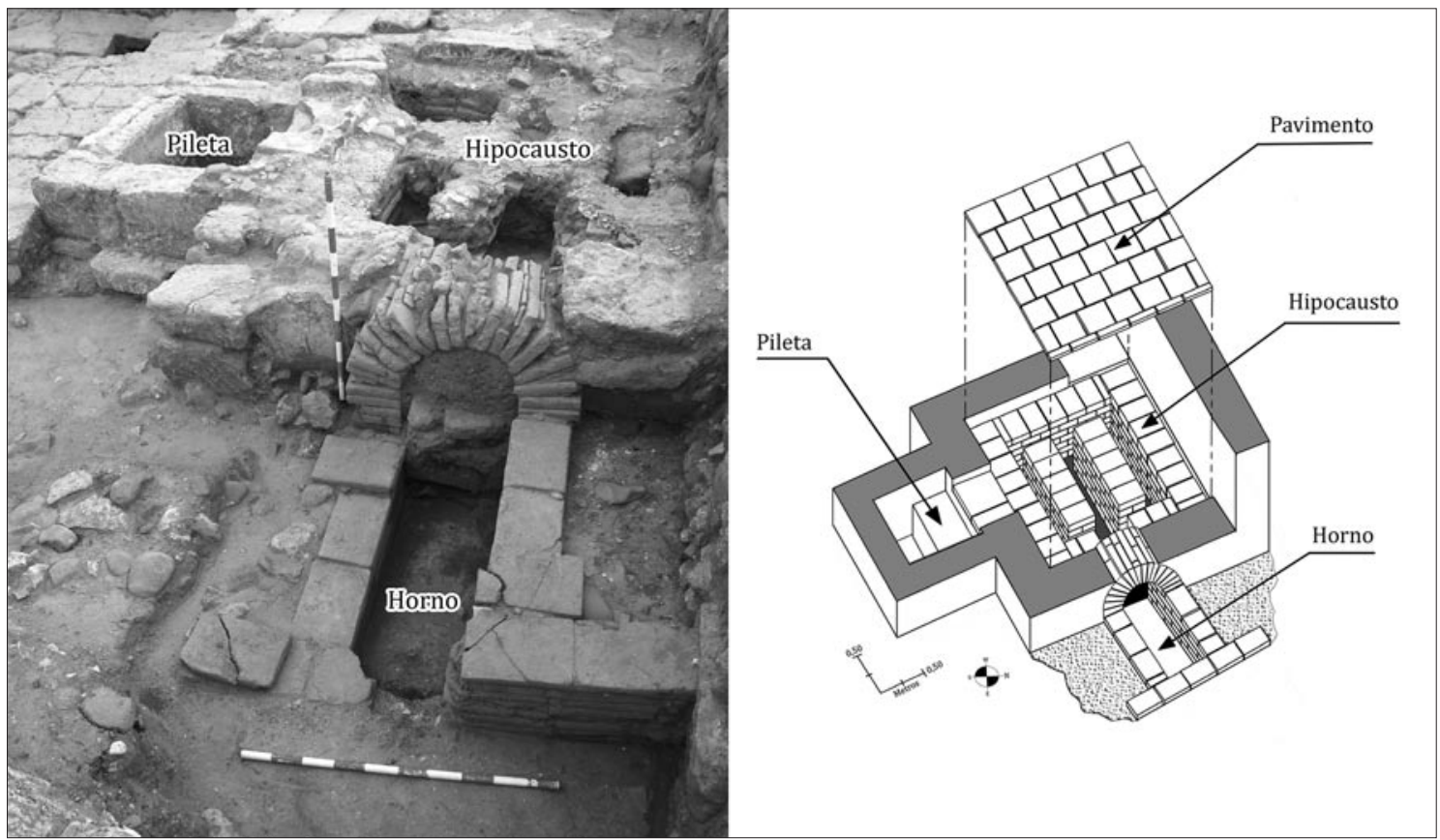

Fig. 6. Sistema de calefacción del baño.

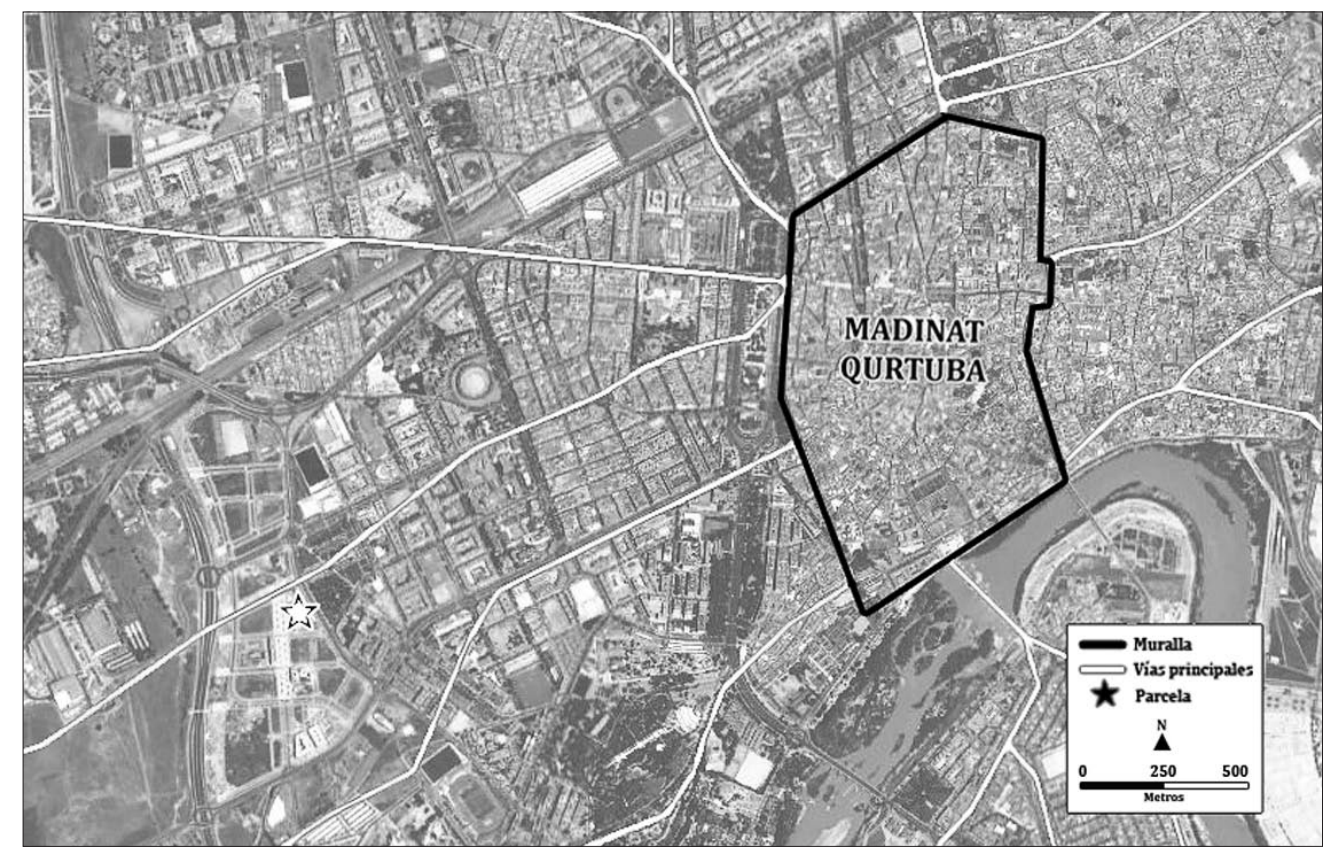

Lám. I. Lám. I. Plano de localización de la parcela en el callejero actual y situación con respecto a la muralla y vías de comunicación en el s.XI. 


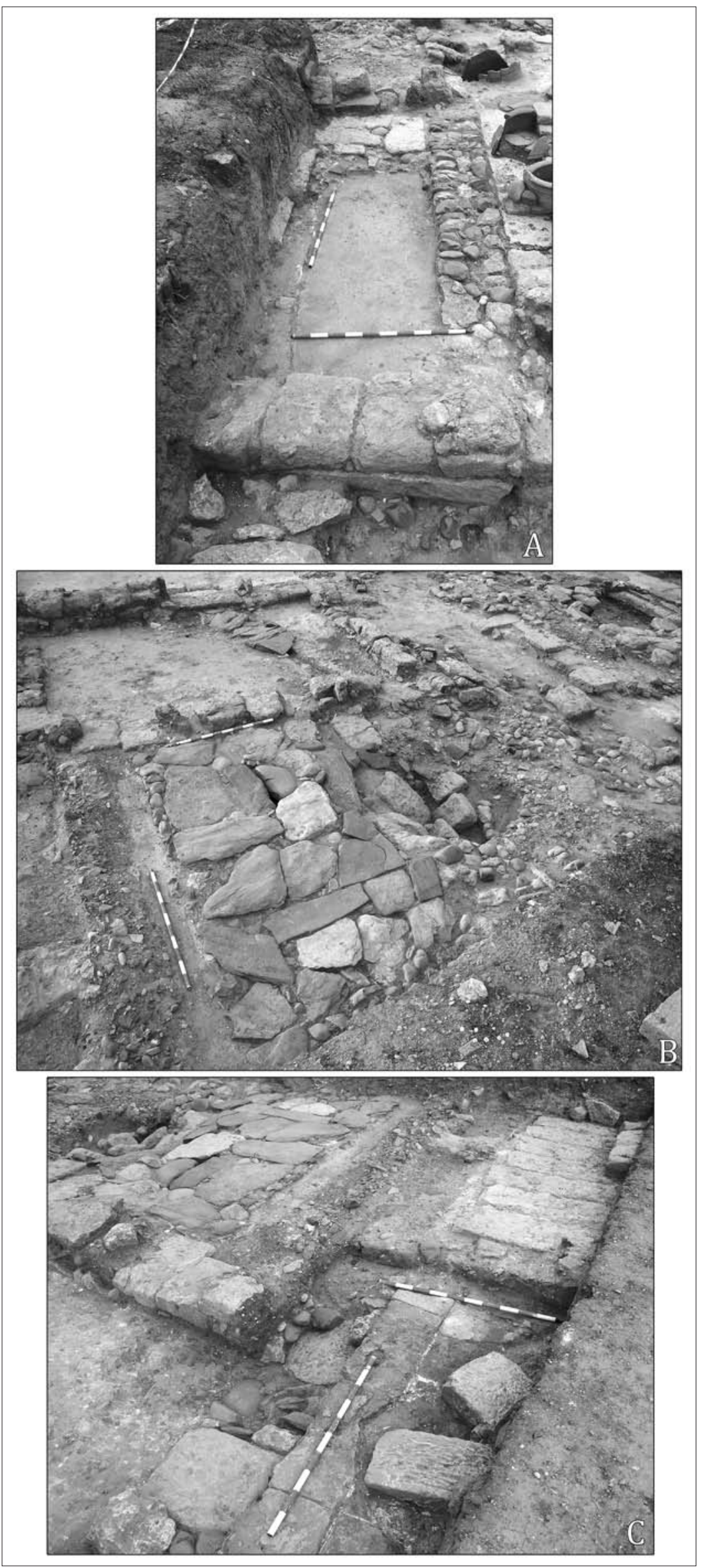

Lám. 2. Área de acceso y

servicio de la vivienda: A)

pequeño espacio documenta-

do en la crujía sur; B) patio;

C) estancias de la crujía oeste, excavadas parcialmente. 
Lám. 3. Área residencial principal: A) patio; B) salón y alcoba en la crujía norte. Se puede apreciar el andén del patio y el vano de acceso a las habitaciones; C) salón secundario, donde se observa la canalización de desagüe procedente del patio.
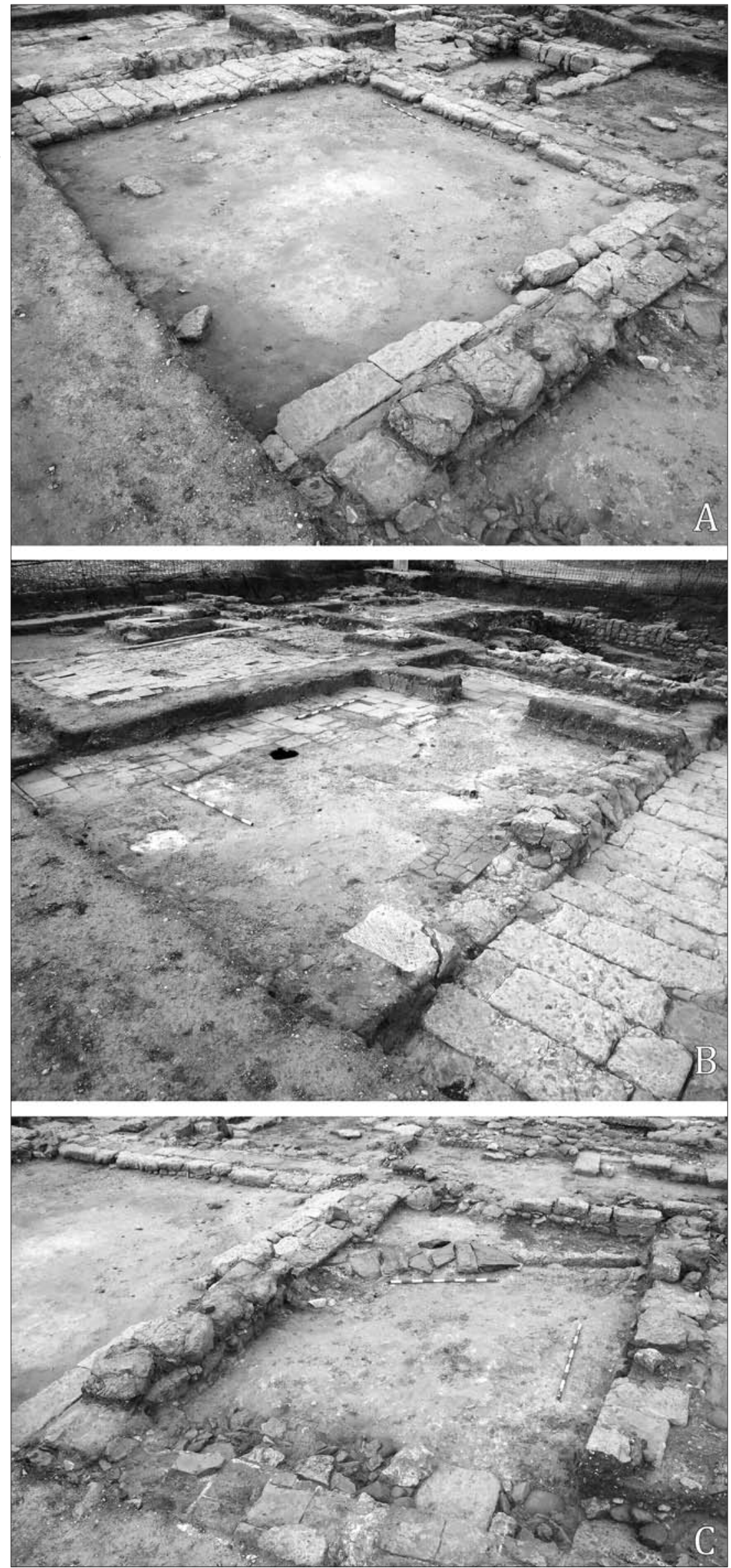

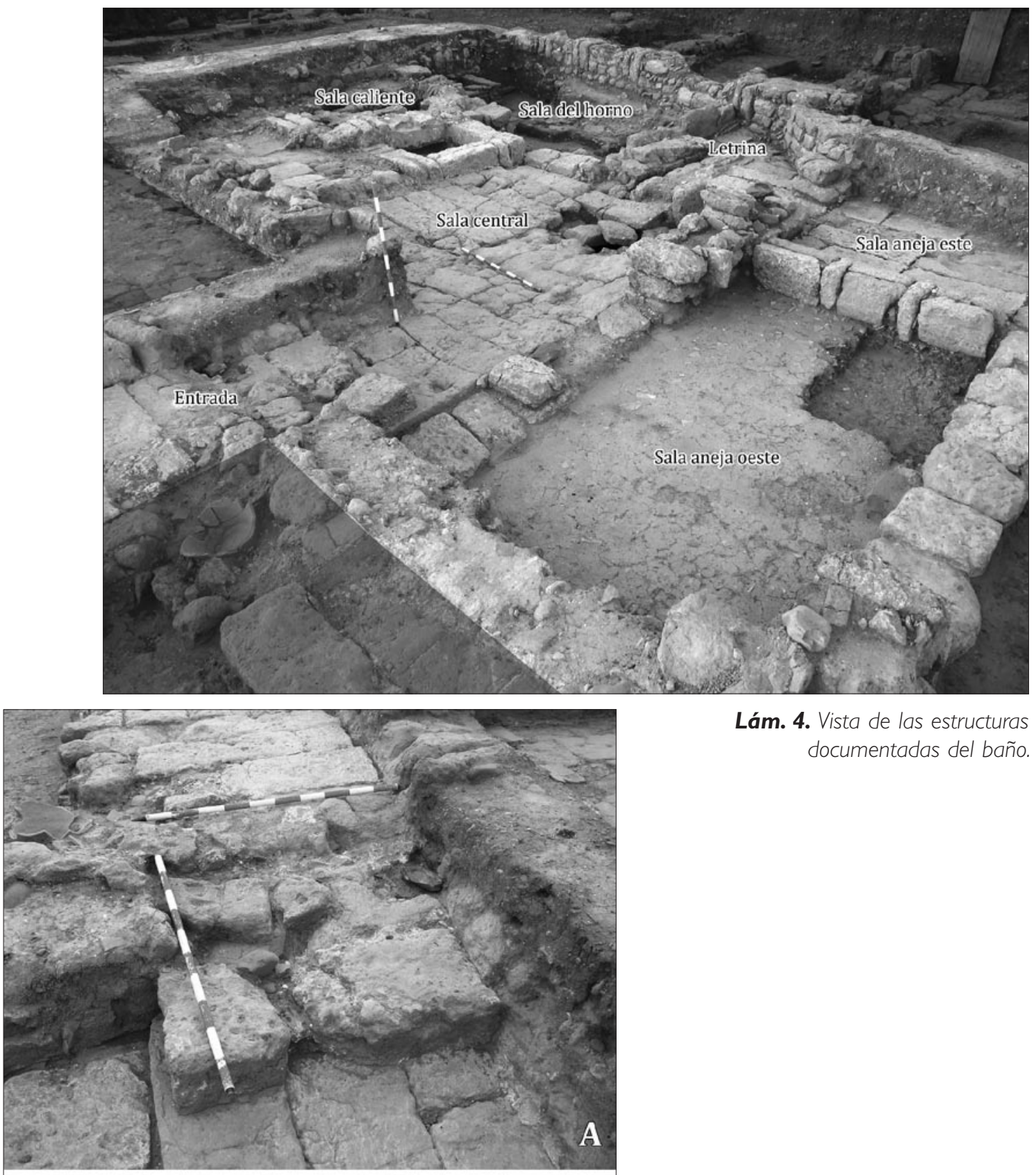

Lám. 4. Vista de las estructuras documentadas del baño.

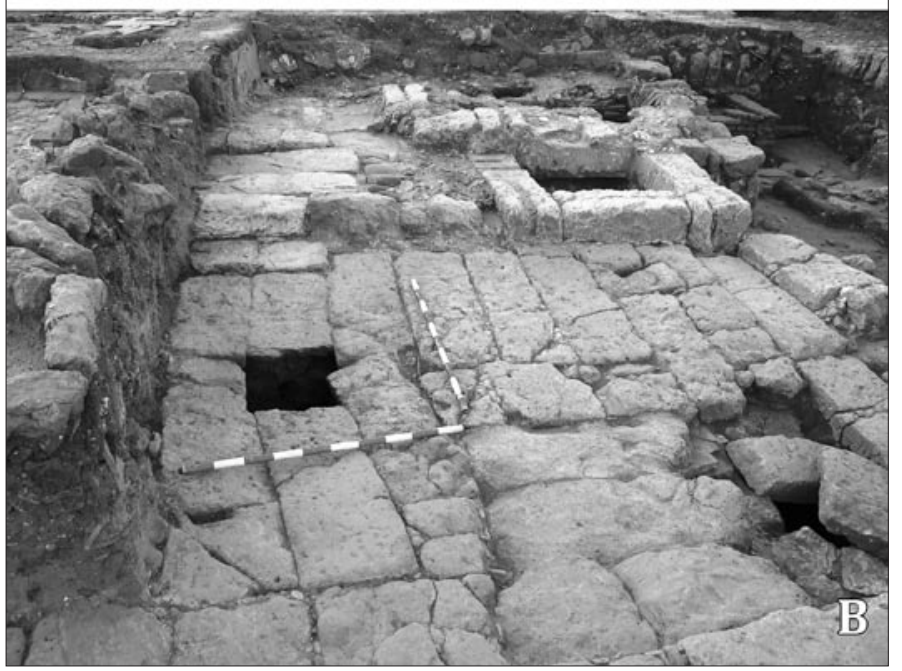

Lám. 5. Vano de acceso al interior del recinto del baño (A), donde se observa el escalón que salva el desnivel con respecto a la cota del patio. Al interior, la sala central (B) distribuye todas las estancias. 


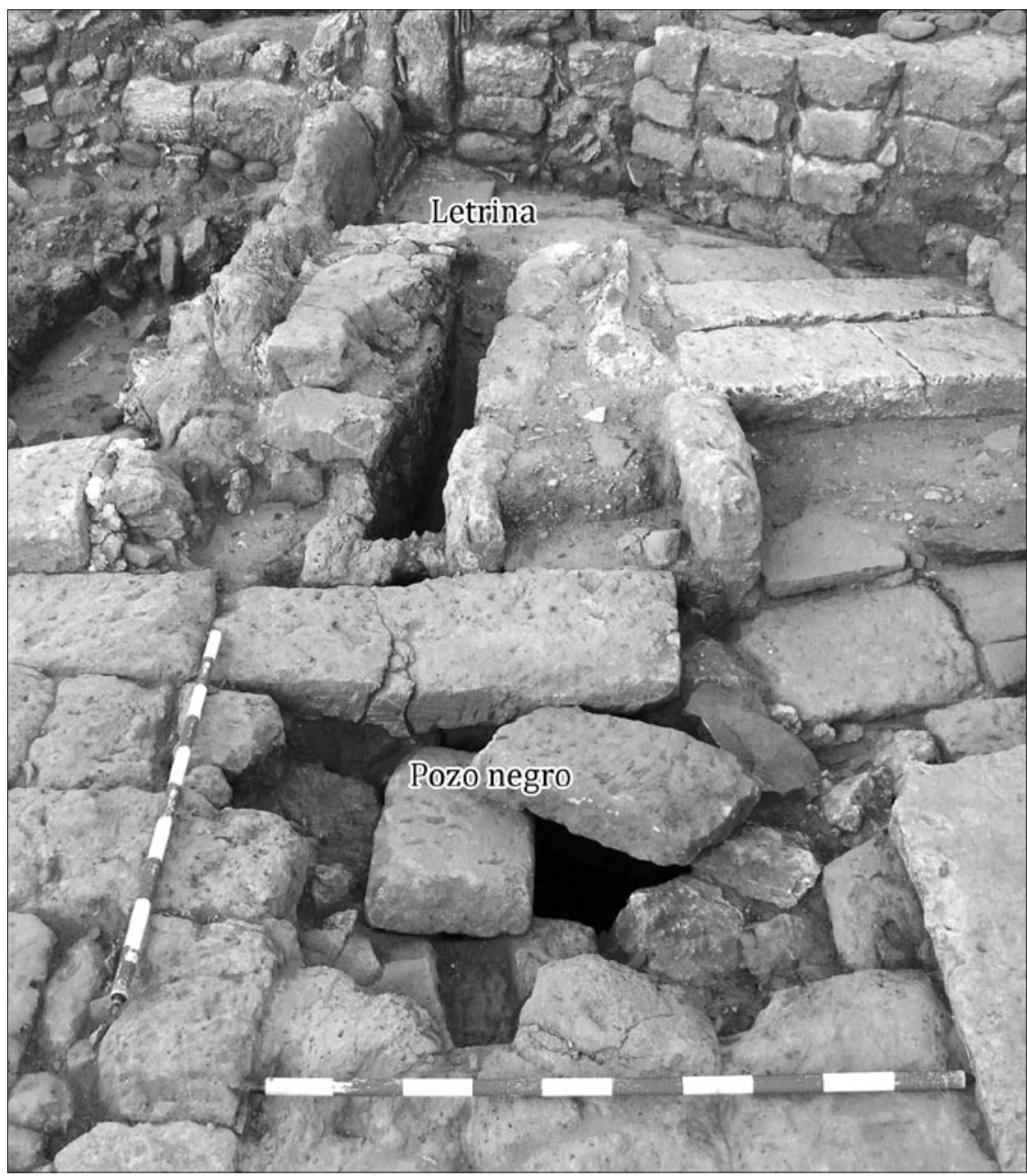

Lám. 6. Vista de la letrina y del pozo negro al que vierte, situado en la sala central.

Lám. 7. Sala del horno, el cual se ubica al fondo de la estancia.

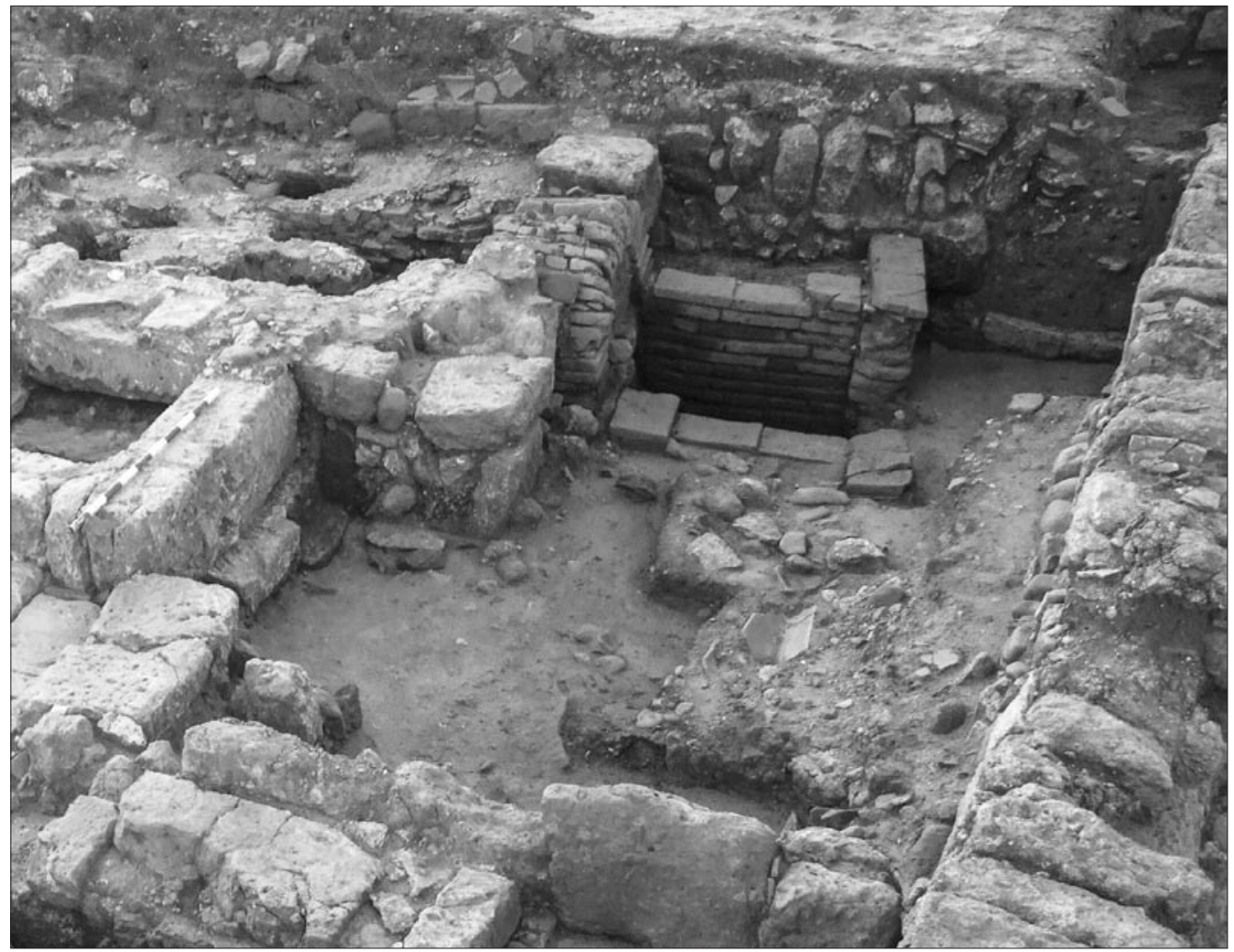



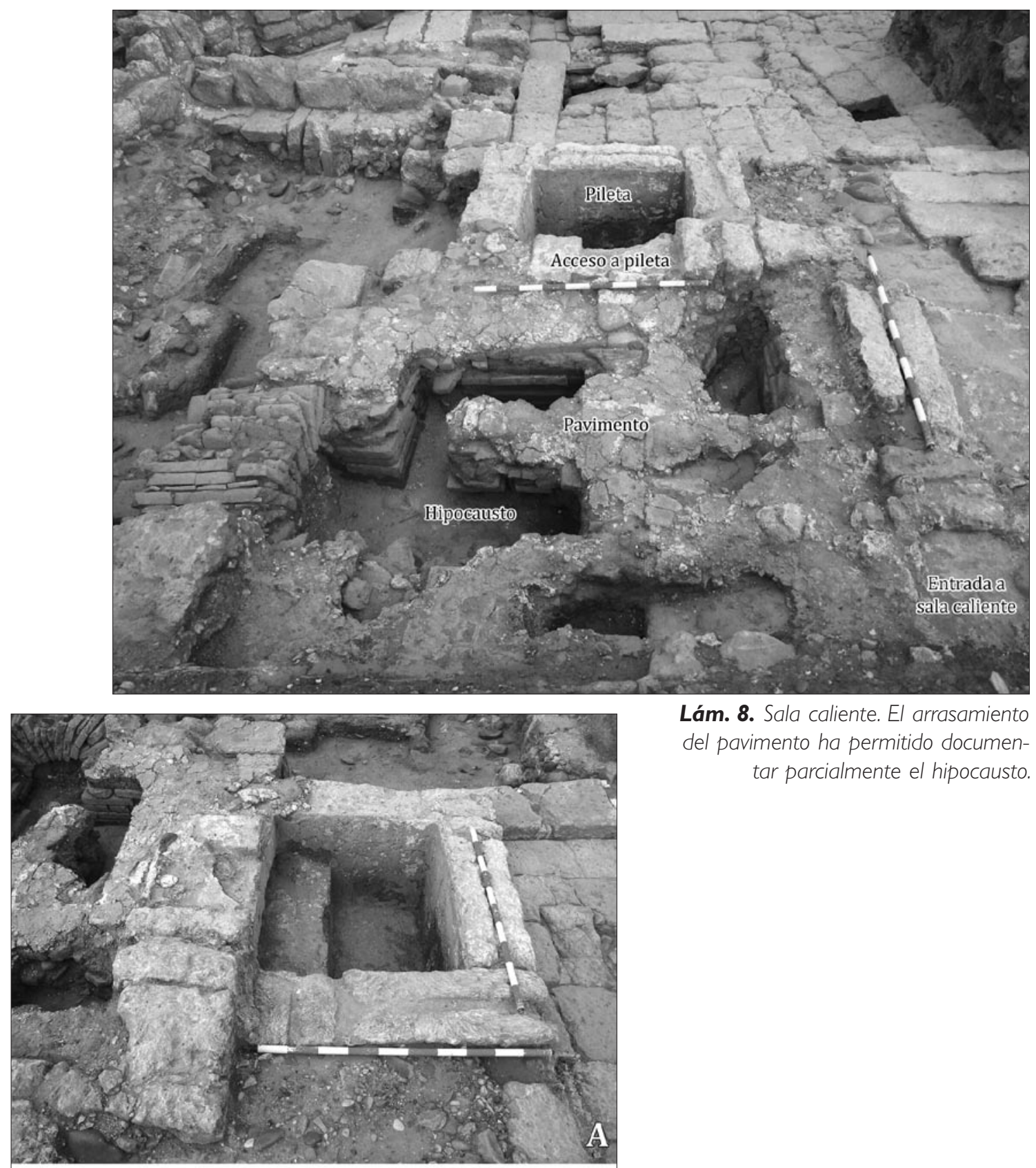

Lám. 8. Sala caliente. El arrasamiento del pavimento ha permitido documentar parcialmente el hipocausto.

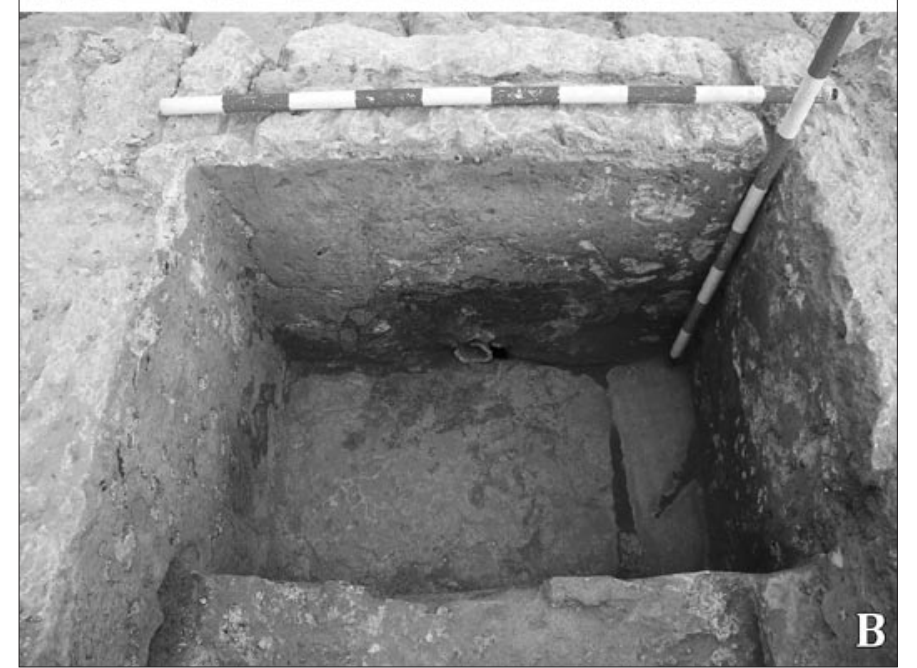

B
Lám. 9. Pileta. El escalón interior (A) facilita el acceso y puede utilizarse de banco. El desagüe se realiza a través de una tubería de plomo (B). 


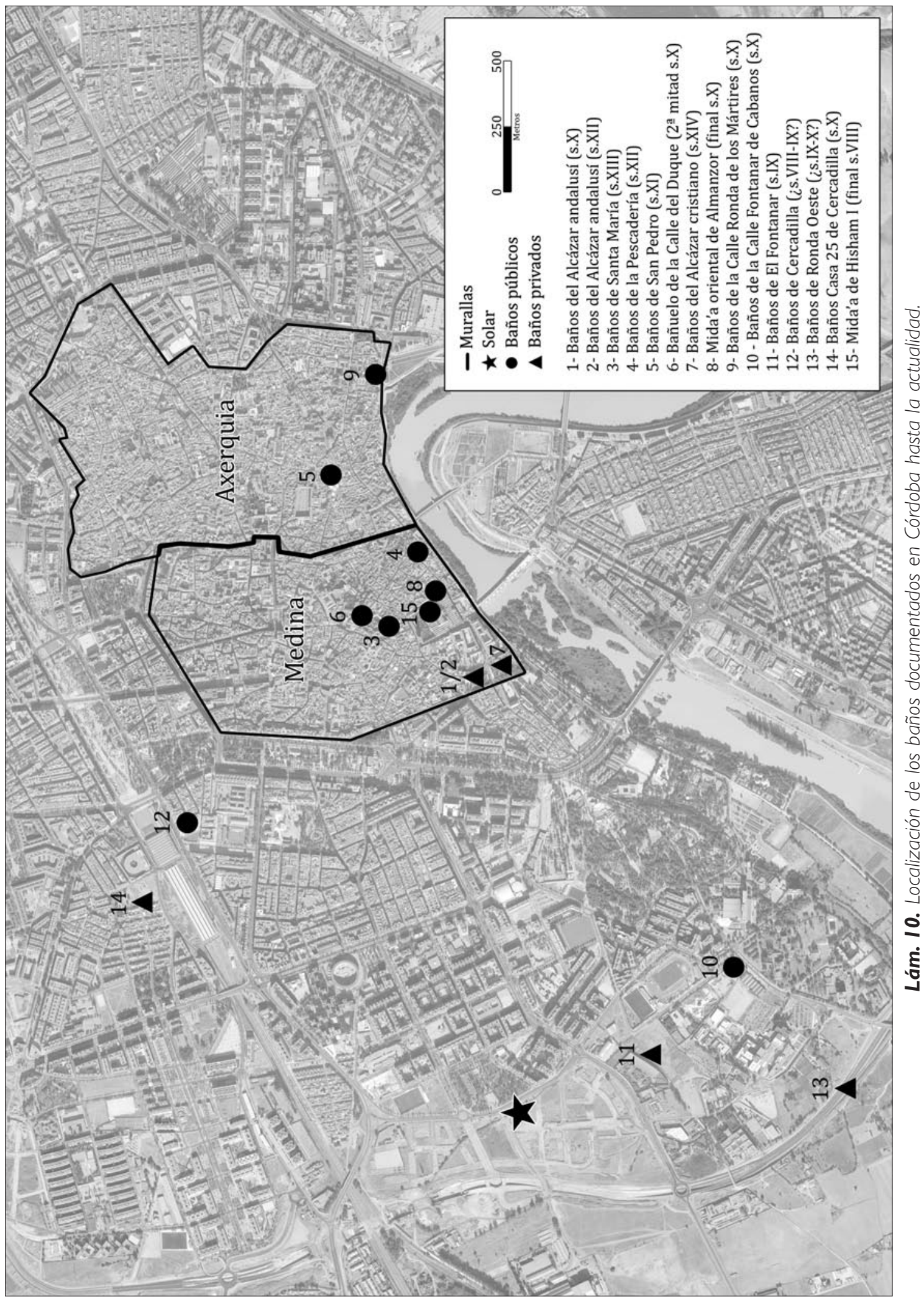

